\title{
Influence of 200 years of water resource management on a typical central European river. Does industrialization straighten a river?
}

\author{
Stefanie Wolf ${ }^{*}$ (D), Verena Esser ${ }^{2}$ (D), Holger Schüttrumpf ${ }^{1}$ (D) and Frank Lehmkuhl²]
}

\begin{abstract}
Background: Over the last 200 years, the courses of most European rivers have experienced significant irreversible changes. These changes are connected to different kinds of anthropogenic river use and exploitation, which have varied from running water mills and rafting to large-scale hydroelectric power plants, industrial water withdrawal and flood protection measures. Today, in most developed countries, water quality and ecological river development are important factors in water management. The aim of this study is to evaluate the specific impacts of different time periods during the last 200 years on river courses and their effects on current river management using the example of the 165-km-long German Rur River (North Rhine-Westphalia). The Rur River is a typical central European upland-tolowland river whose catchment has been affected by various phases of industrial development.

Methods: In this study, a range of morphological changes over the last 200 years are determined based on historic maps and up-to-date orthophotos. River length, sinuosity, oxbow structures, sidearms and the number of islands are used to investigate human impact. The results are correlated with historic time periods.

Results: This analysis shows that river straightening increases, especially during the Industrial Revolution, even without direct hydraulic channelization. The period and grade of river straightening have a direct morphodynamic impact on today's river restorations. Since the Rur River is a typical upland-to-lowland river, the results show an additional impact by geofactors, such as landform configurations.

Conclusions: Morphodynamic development is correlated with five historic periods of industrial development between 1801 and 2019 up to the introduction of the EU—Water Framework Directive (EU-WFD). Each period shows a different influence on the watercourse, which is connected with human intervention. Even if worldwide comparisons show that the five historical phases differ slightly in their timing between regions, they are applicable to other study areas.
\end{abstract}

Keywords: Tipping point, Human impact, Industrialization, River course development, River straightening

\section{Background}

History of human influence on river systems

Rivers are one of the most anthropogenically influenced ecosystems in the world [1]. Most European rivers have

\footnotetext{
*Correspondence: wolf@iww.rwth-aachen.de

${ }^{1}$ Institute for Hydraulic Engineering and Water Resources Management, RWTH Aachen University, Mies-van-der-Rohe-Straße 17, 52056 Aachen, Germany

Full list of author information is available at the end of the article
}

experienced extensive channel changes, whereby the human impact is an important key driver [2,3]. Since the beginning of the Holocene, the influence of humans on the environment has continuously increased [4-6]; hence, many fluvial systems have been negatively and profoundly influenced worldwide by human actions for centuries [7-12]. In the early Holocene, rivers were mainly anabranching, which changed in the late Holocene [3]. While geomorphologic changes before the 
late Holocene are mainly attributed to climatic factors $[4,13]$, the establishment of agriculture and large-scale deforestation in the Neolithic period led to a tipping point $[14,15]$. Increased human land use has led to siltation of secondary channels, which changes river morphology [3].

The first hydraulic engineering measures were river straightening, dam and weir construction and the construction of mill canals and ponds $[13,16]$. In the Middle Ages, as the main energy source, the establishment of water mills increased dramatically [17].

Various studies have investigated human impacts on river systems worldwide at different times $[7,8,18,19]$. Gibling evaluates human influences using worldwide examples and creates a timeline divided into six phases from the late Pleistocene to the Holocene [19]. He emphasizes that in many cases, serious changes were connected with the Industrial Revolution and technological advances in the twentieth century, which are included in his 6th phase, the Technological Era (after $1800 \mathrm{CE}$ ) (cf. Figure 1).

In the last two centuries, changes in land use, industry, flood protection, drinking water supply and hydroelectric power measures as well as shipping have caused further morphodynamic impacts on fluvial systems [14, $20,21]$. In particular, the development of automated production and the steel industry has caused a higher demand for hydroelectric power, process water and transportation routes provided by waterways [22-25]. In the late-nineteenth century, the Industrial Revolution led to changes in river morphology throughout Europe [26, 27]. The alpine Rhone, Isar and Danube Rivers, for example, were channelized in the mid- to late-nineteenth century, causing braided structures and large gravel bars to form [28]. The Tisza River in Ukraine and Hungary has shortened by approximately $30 \%$ through river training [26]. Therefore, the increased use of fossil energy from 1950 onwards can be linked to rapid river degradation and river pollution in the Western World [27, 29-31]. Although sewage systems were introduced, pollution from industry, agriculture and urban areas since the late-nineteenth century has led to long-term changes in river ecosystems $[27,32]$.

Today, industries are still dependent on the water supply and hydroelectric power [33, 34], and it is expected that anthropogenic influences on rivers will continue to increase $[35,36]$. Apart from that, in recent decades, a rethinking of the protection of fluvial systems has occurred. Especially in Europe, sustainable development of water bodies has become a common goal with the legislative basis of the EU-WFD [37]. Therefore, the timeframe from the Middle Ages to modern times is considered to have had the largest impact on lateral channel movement due to hydraulic structures [33].

\section{Five phases of river management on the Rur River}

Hence, the culture of river management has changed several times within the last 200 years. Focusing on the history of industrial development, this study period of 200 years can be divided into five phases of river management of the Rur River (cf. Figure 2). Thus, each phase has different water management characteristics on which the emphasis is placed. The phases are to be understood as cultural epochs, and the time divisions are determined using the example of the Rur catchment. Cultural epochs are generally variable in time and space $[38,39]$.

Interventions in water bodies in favor of industry started in the Pre-industrial Phase (1) in the eighteenth century with lignite and ore mining [40-42]. In the nineteenth century, as a result of water conflicts between agriculture and industry, textile companies were given preferential treatment [42].

In the Industrial Phase (2), rivers were primarily used for water-demanding industries. In this phase, in the Rur catchment, water-demanding industries, such as sugar cane and paper industries, settled near rivers in Aachen as well as Jülich and Düren [42, 43]. Increased water demands of industries led to a water crisis [42] and finally to the construction of larger dams from 1900 onwards, which ultimately had a greater impact on flowing waters [44].

The Industrial Phase (2) is superseded by the Agricultural Phase (3) after World War I, where large area structural changes for food production and a shift from water power to electricity occurred. Important land use changes occurred after the late 1940s when intense agriculture and rapid urbanization developed [45]. After World War II to the early 1980s, the reclamation of floodplains for agriculture as well as expanding settlements were the main goals of river management $[42,43]$. Since 1980, water quality and the environment have been the focus (Phase of Ecological Improvement, 4). In 1986, waterbodies were recognized as part of ecosystems for the first time in the Federal Water Act in Germany [46].

Today, we are in the second management cycle of the EU-WFD (Water Framework-Directive) [47], the Phase of EU-WFD (5) (cf. Figure 2). Sustainability of running waters and renaturation largely determine the actions of people [48], but industries are still large stakeholders in water management $[49,50]$.

In this context, the increased use of water resources as well as flood protection are often connected with 


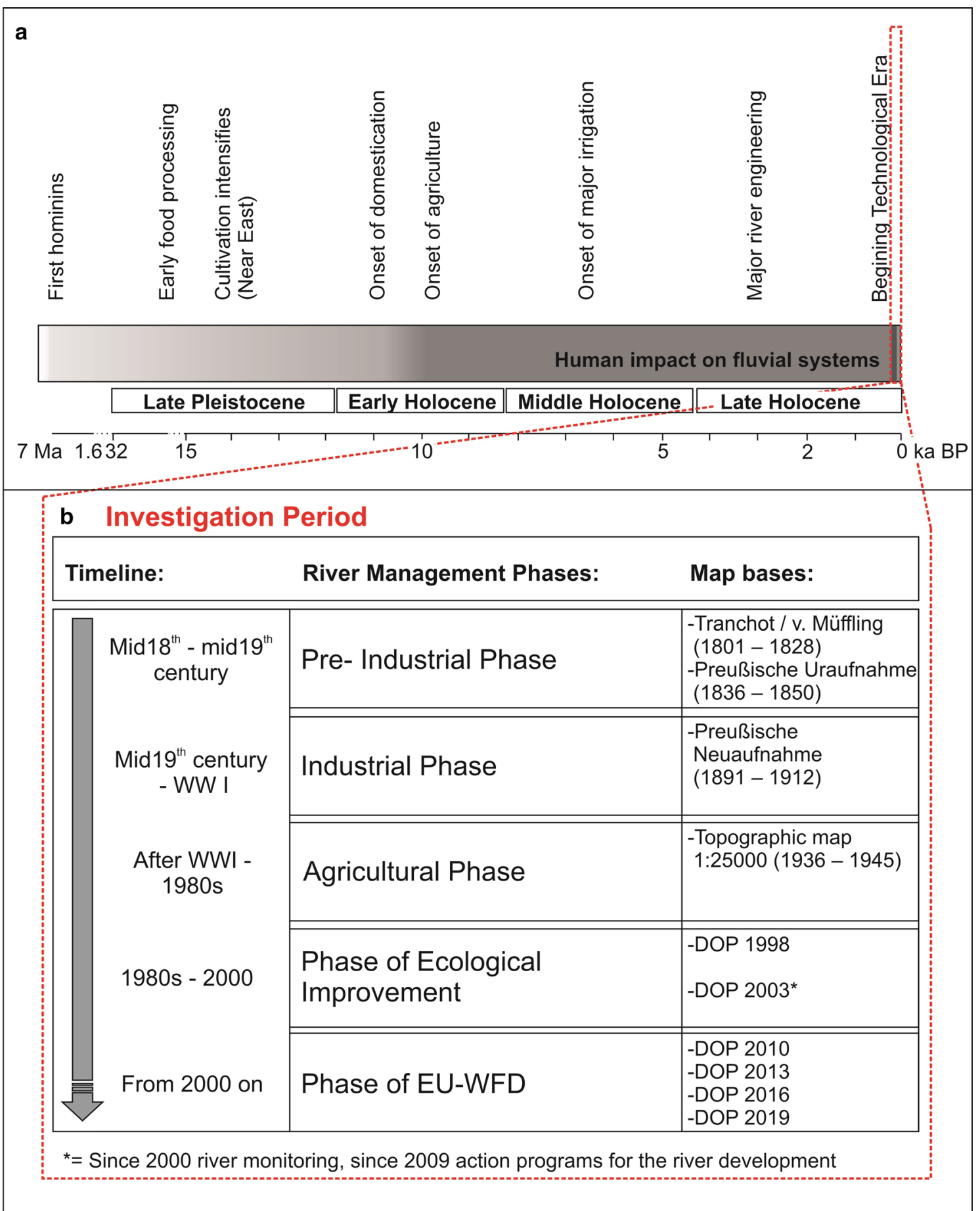

Fig. 1 a Tipping points of human development, $\mathbf{b}$ classification of the five phases of river management in the Rur River catchment into phases of human impacts on river courses worldwide. Source: own illustration modified after [19]

riverbed regulations $[25,51]$, but does industrialization truly straighten a river?

Despite the massive anthropogenic influences, geofactors of riverine landscapes still affect the morphology and hydrology of rivers and their floodplains today [52]. Irreversible tipping points in watercourse development are highly dependent on the nature of the catchment area, which is why watercourses 


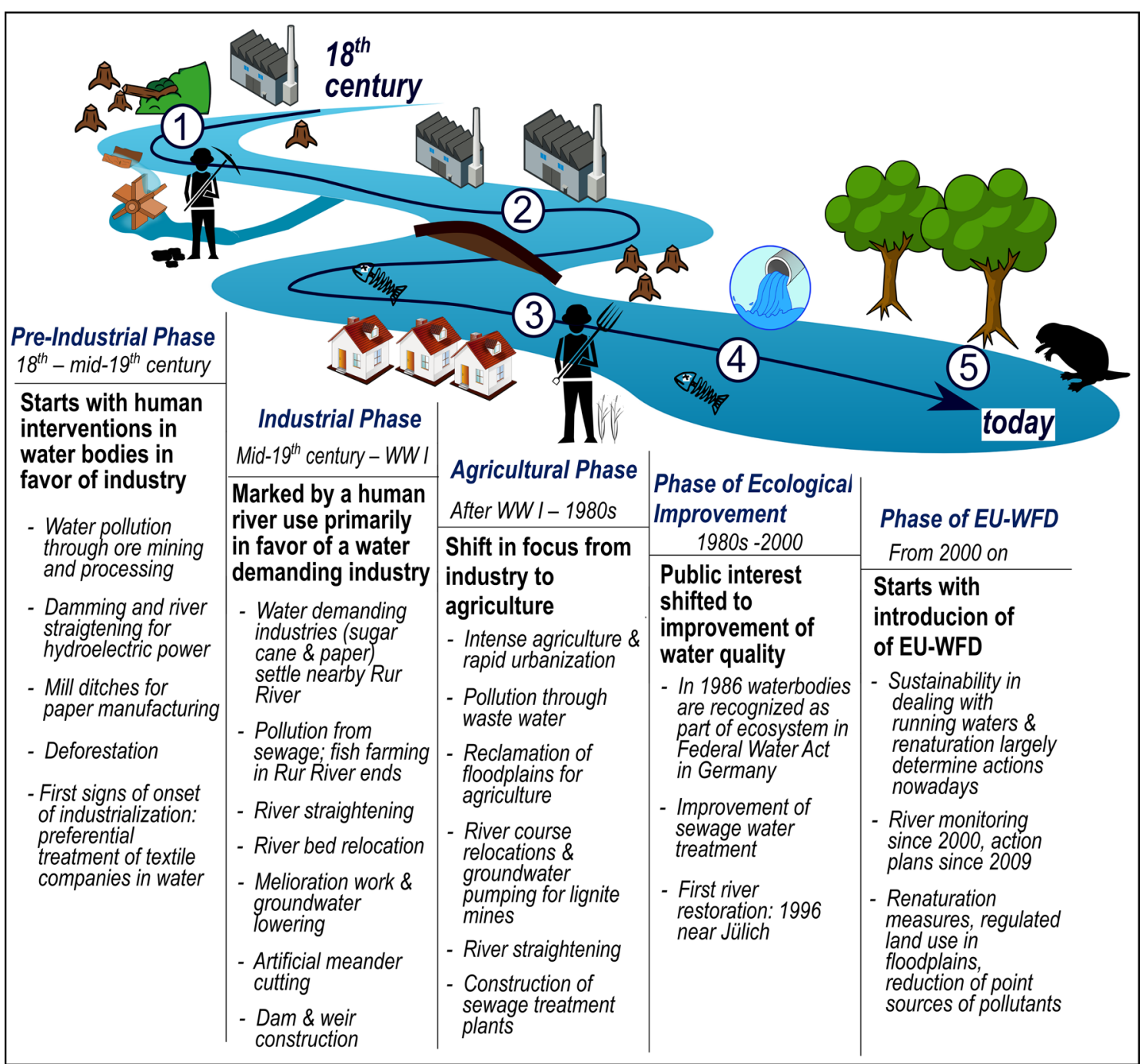

Fig. 2 The five phases of river management in the Rur catchment over the last 200 years, definition and characteristics. Source: own illustration, data according to [41-43, 45-48, 77, 129-135]

react with varying degrees of sensitivity to a particular anthropogenic impact [53, 54].

\section{Human influences on morphodynamic structures Sinuosity, oxbows, braided and anastomosing structures}

Oxbows often develop from meander cut-offs $[55,56]$ and therefore are a sign of river straightening. Generally, a low degree of sinuosity indicates anthropogenic disturbance [57]. According to Gibling (2018), human impacts cause changes from meandering to braided planforms and from multithread channel to single-channel riverbeds [19]. With a decreasing main channel sinuosity, a change from anastomosing to braided channels is common [58]. Braided streams are generally characterized by low sinuosities [59]. Therefore, braiding is a general indicator of river straightening. When sinuosity decreases and braiding increases, the development is often accompanied by higher peak flows and higher monthly discharge variability [59]. These changes in discharge are commonly caused by human activities, such as deforestation, mining and agriculture [60]. If a channel is anastomosing or braided, it depends on the sediment supply from upstream [61]. For example, Scorpio et al. (2018) found that braided structures only formed downstream of sediment confluences that were rich in sediment in the alpine Adige River [62]. Braided rivers have a high supply rate but a low transport capacity, which leads to the deposition of material [63]. Downstream of artificial river straightening higher river bank erosion occurs due to bedload deficits $[57,64]$, which explains changes 
from anastomosing to braided channels. Anastomosing structures are more common for lower slopes and nonconfining thalwegs [55]. The main sediment transport is suspended load [55]. Anastomosing channels have a relatively low ability to erode and transport sediment [63] and therefore develop towards a natural equilibrium.

\section{Side arms and islands}

A marker of a natural and unspoiled bedload balance is a high morphological development capacity leading to the formation of islands and side channels [57]. Usually, hydraulic forces in channelized river sections are too high for island formation [65]. Islands reestablish when river channelization is dismantled [65] and are therefore a sign of increasing structural diversity. The dynamic equilibrium of a river is shown in small-scale changes, such as island formations [66]. Side arms vanish during times of high sediment input due to siltation and are restored through river management actions [67]. Therefore, they increase the structural diversity of the river.

\section{Scope of present study}

The aim of this study is to assess the correlation between river management in the last 200 years and the changes in river courses by means of historic maps and digital orthophotos using the Rur River as an example. Comparable studies showed that these types represent valuable sources for information on river channel changes and that the period of analysis should be at least 100 years [68]. Therefore, large-scale morphological changes over the last 200 years are determined using the following indicators: river length, sinuosity, oxbow structures, sidearms and number of islands. Due to the importance of the Technological Era after Gibling [19], this period is subclassified into different river management phases. Understanding the interaction between human influences and changes in fluvial systems from the past is the key to sustainable river management in the future.

Therefore, periods of hydraulic development, including industrialization, in the study area, the Rur River catchment (North Rhine-Westphalia, Germany), are compiled from the literature (cf. Figure 2). The influence of these phases of water management on the Rur River can be distinguished from each other via clearly formulated definitions. Afterwards, different historic maps and morphodynamic indicators are used to assess whether those periods lead to specific morphodynamic changes of the river within the specific Phases 1-5. Changes in river straightening and structural diversity of the river are determined from changes in the indicators by simple formulas. Differences between low mountainous regions and lowlands are also considered to address the impact of geofactors. Finally, the transferability of the results to river systems worldwide is discussed.

\section{Study area}

To investigate the long-term effects of anthropogenic influences on fluvial systems, especially during industrialization, the Rur catchment (North Rhine-Westphalia, Germany) was chosen. Changes in smaller catchments have direct effects on the fluvial system, and morphological investigations are possible with higher spatial resolution $[8,69]$. Hence, the Rur River catchment is particularly suited since it is of a moderate size with 2,361 $\mathrm{km}^{2}$ [70]. It also extends from the mid-mountainous area of the northern Eifel Mountains in its upper reach to the lowlands of the Lower Rhine Embayment in its lower reach [71]. The springs of the $165-\mathrm{km}$-long Rur River are located in the raised bog area of the High Fens in Belgium at an altitude of $660 \mathrm{~m}$ above sea level [70]. In the Dutch city of Roermond, the Rur River flows into the Meuse River at an elevation of $30 \mathrm{~m}$ above sea level [70]. Approximately $6.7 \%$ of the Rur catchment is located in Belgium, approximately $4.6 \%$ is within Dutch territory, and almost $90 \%$ is located in Germany [72]. The catchment area of the Rur River comprises 7\% of the Meuse catchment area, but it is the only river in the catchment that is significantly regulated by dams, which balance the water levels [71].

After approximately 10 river-km in Belgium, the upper reach of the Rur River flows through the Eifel, a low mountain range in Germany [73]. The Eifel is one of the most rural areas in Germany [74]. The catchment is wholly anthropogenic, marked by forestry in the highlands and grassland and farmland on the plateaus [71]. The Lower Rhine Embayment is marked by agriculture [75] and lignite open cast mining [71]. The largest cities in the catchment are Aachen, Düren, Stolberg, Eschweiler and Heinsberg in Germany and Roermond in the Netherlands, which are all located in the middle and lower catchments of the Rur River (cf. Fig. 3).

North Rhine-Westphalia has a comparatively humid but cool climate due to its proximity to the Atlantic Ocean [71,76]. Precipitation in the Eifel Mountain region is significantly higher than that in the northern lowlands [71]. Due to its source region in Eifel, the year-round aquiferous and dam-regulated Rur River has a rain- and snow-influenced discharge regime and is affected by snowmelt from the low mountain range [43].

Related to climatic characteristics, the river regime is pluvio-nival with the highest discharge in winter and long periods of dry weather runoff in summer. Flood events occur mainly in spring and winter due to prolonged rainfall or snowmelt and in summer due to storm events. Due 


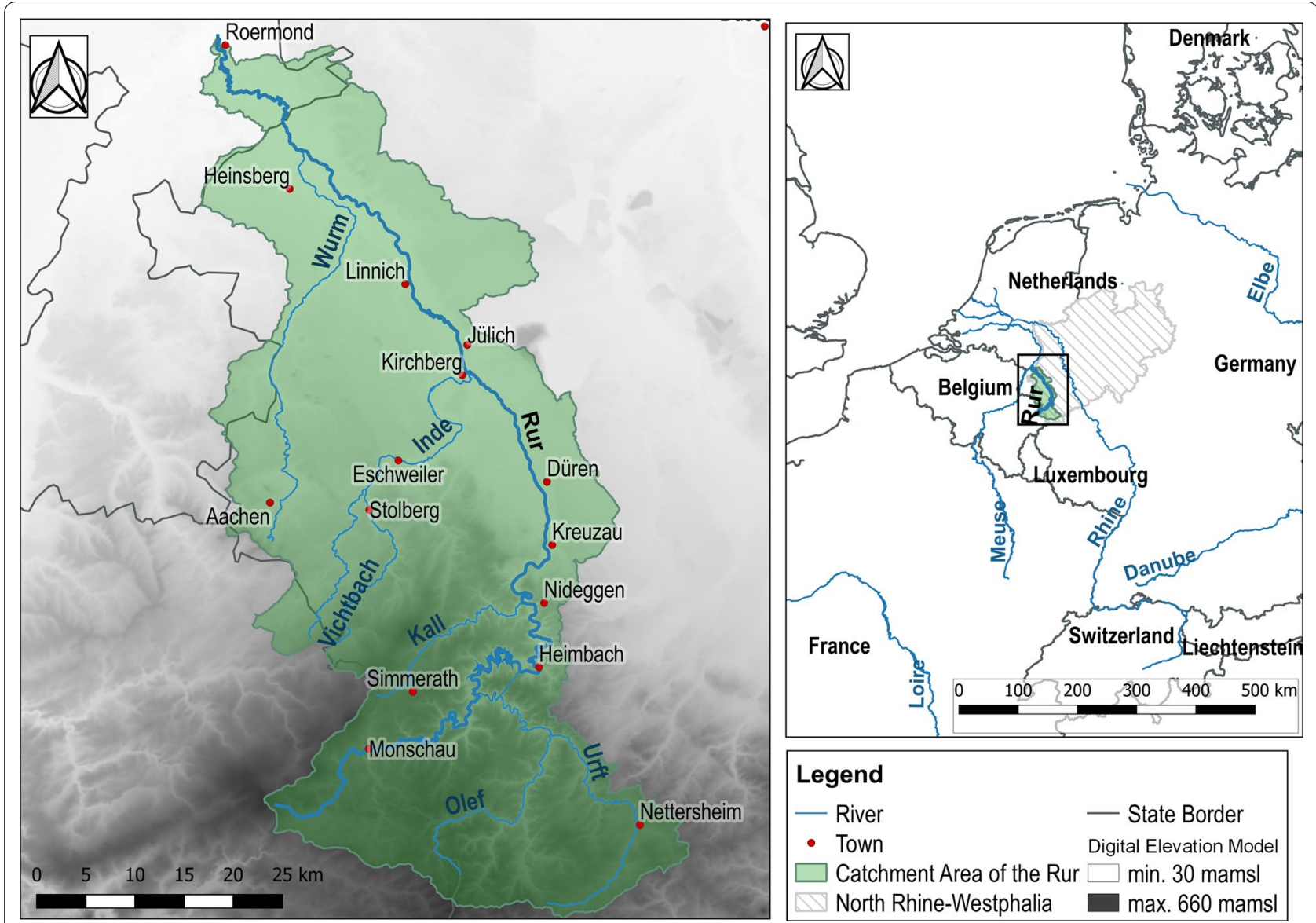

Fig. 3 Overview of the Rur catchment and its location in Europe. Source: own illustration; DEM: [136] ; river system: [137, 138]; towns: [139]; country borders: [140]

to the dams, the discharge of the Rur River is regulated; thus, runoff peaks are smaller $[41,43]$.

In the last 200 years, northern Eifel has been characterized by urbanization, grassland cover of arable land in the low mountain ranges and foothills, and reforestation measures in the Eifel forests [77]. Today, the Rur River is strongly anthropogenically influenced. Private companies, especially those in the paper industry, are still the largest water consumers in the Rur-Eifel region to date [76, 78]. Most days of the year, various reservoirs in the upper catchment withdraw a reduced amount of water, which is morphodynamically ineffective [78]. The largest settlement on the Rur River in the low mountain range is Monschau, where massive bank protection characterizes the river (cf. Fig. 4b). In the low mountain range, the Rur River is categorized as a German river type 9 , indicating a silicate, low mountain range river rich in fine to coarse material. The course of the river today in the upper catchment is partially similar to the ecological mission statement, which calls for stretched to slightly sinuous, natural sections existing with numerous characteristic longitudinal benches, sliding slopes and riffle pool sequences $[79,80]$. Side channels would be characteristic but are missing [79]. In the lowlands, the Rur River is categorized as a German river type 17, indicating a gravel-embossed lowland river [73]. Immense hydraulic engineering between the 1940s and 1970s led to a completely embossed straightened channel with strong incision [80]. Additionally, the flow is regulated by dams, and a large number of transverse structures restrict continuity [80]. Nevertheless, near-natural sections can be found in the lowlands between Schophoven and Kirchberg and between Jülich and Linnich (cf. Fig. 4f)) [80].

\section{Focus regions}

The three focus regions cover one section each of the upper (A), middle (B) and lower (C) reaches of the Rur catchment (cf. Figure 5; Table 1). Focus region A and focus region B cover the Rur segments that are siliceous, low mountain rivers rich in fine to coarse material (German river type 9). In focus region $C$, the Rur River is 

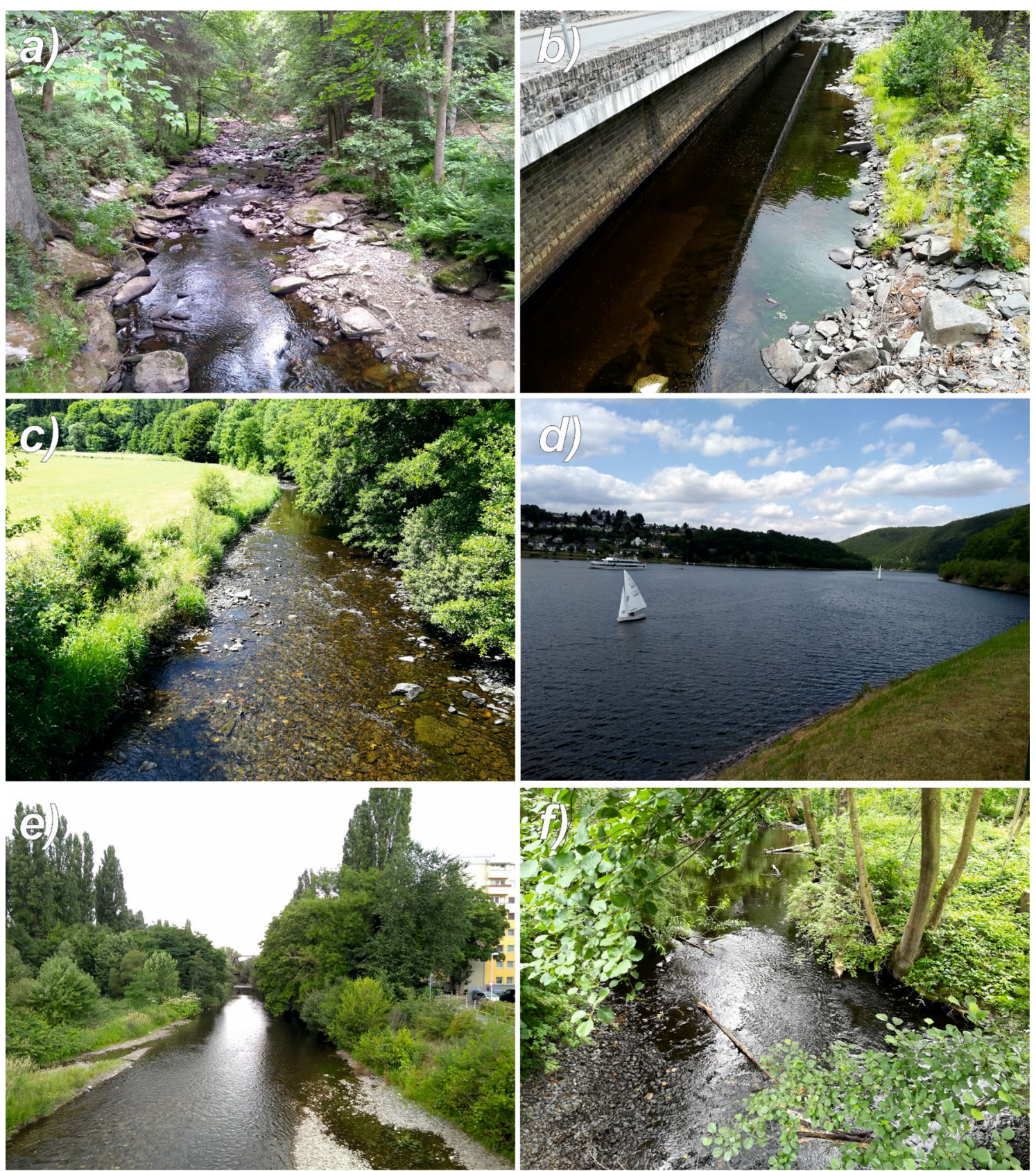

Fig. 4 a Upper reach near Monschau, b bank protection in Monschau City, $\mathbf{c}$ upper reach in focus area A, d Rur Dam, e middle reach in focus area B in Düren city, and $\mathbf{f}$ example of a near-natural section in the lowlands before Düren. Source: own illustration

characterized as a gravel-embossed lowland river (German river type 17).

Focus region $\mathrm{A}$ is located upstream from the dams starting at the end of the village of Monschau. In the low Eifel mountain range around Monschau, large riverbed shifts are topographically not possible. Therefore, characteristic waterway bends are used to mark the start and end of the focus region. Focus region B, which is $20 \mathrm{~km}$ long, covers a typical agricultural area. In this focus region, the city of Düren plays an important role in industrial development in the Rur catchment. As a transshipment point for rafted wood in the Middle Ages, it later became the main location for the paper industry, and afterwards, sugar cane factories 


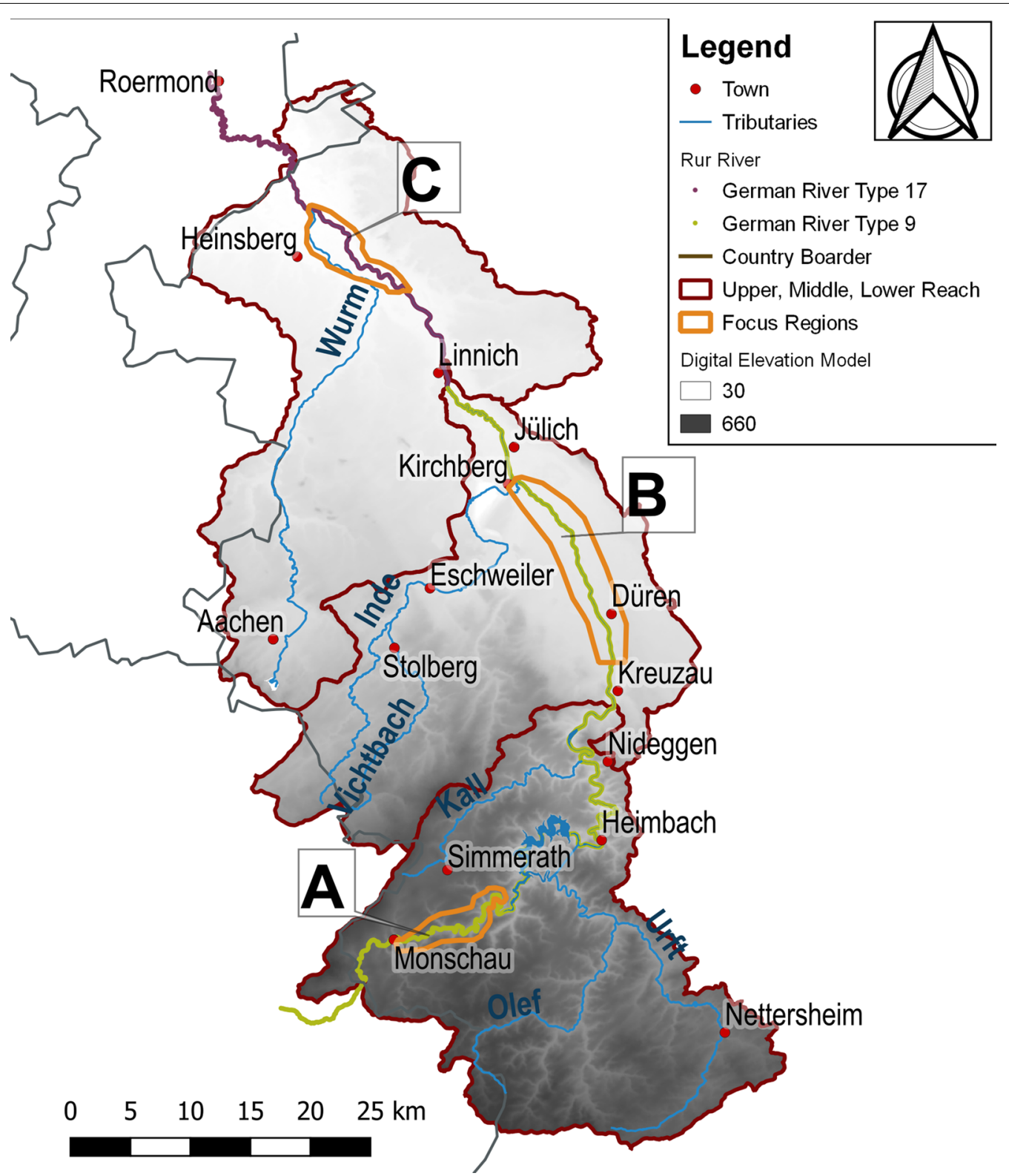

Fig. 5 Focus region; source: own illustration; DEM: [136]; River system and catchment area: [137, 138]; towns: [139]; country borders: [140]; German river type: [71]

Table 1 Characteristics of the focus regions

\begin{tabular}{|c|c|c|c|c|}
\hline & \multirow[t]{2}{*}{ Mid. elevation } & \multirow[t]{2}{*}{ Slope } & \multicolumn{2}{|c|}{ Average discharge } \\
\hline & & & Winter & Summer \\
\hline & (m.a.m.s.I.) & (\%) & $\left(\mathrm{m}^{3} / \mathrm{s}\right)$ & $\left(\mathrm{m}^{3} / \mathrm{s}\right)$ \\
\hline Focus Region A & 395 & 0.7 & 5.7 & 3.9 \\
\hline Focus Region B & 100 & 0.3 & $12.0^{*}$ & \\
\hline Focus Region C & 30 & 0.1 & 26.7 & 17.8 \\
\hline
\end{tabular}

* No detailed data for summer/winter available (cf. Fig. 6). Focus region B is located downstream from today's dams, and the Inde tributary marks its lower boundary. The Wurm tributary marks the lower boundary of the $15 \mathrm{~km}$-long focus region $\mathrm{C}$.

\section{Methods}

To analyze the river course development over the last 200 years, historic maps and digital orthophotos are evaluated in three focus regions (cf. Fig. 7). 

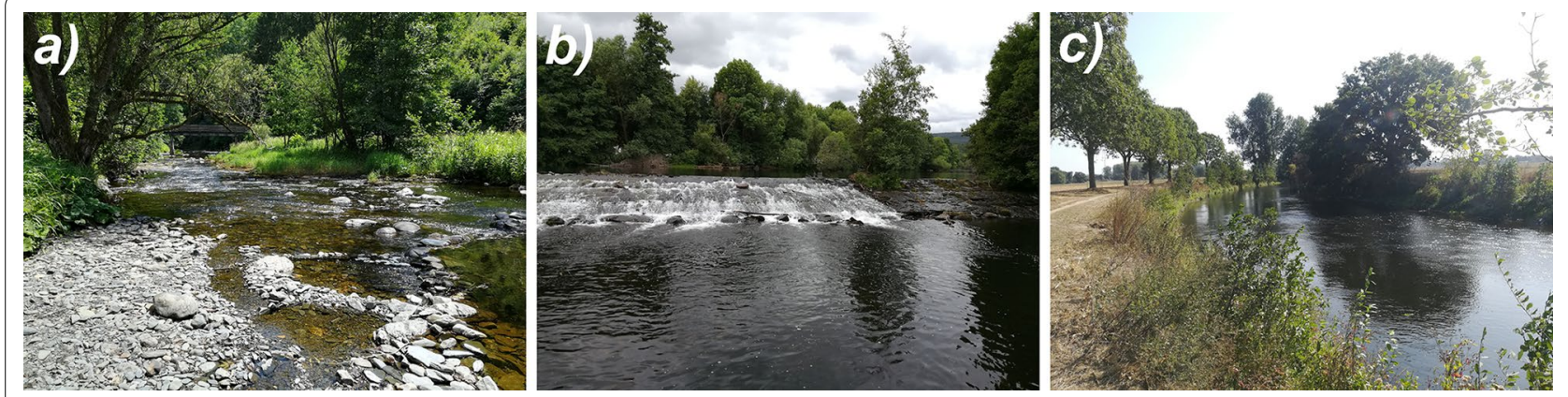

Fig. 6 Impressions of the Rur River from the three focus regions. a Rur River below Monschau, b Rur River near Düren, and c Rur River near Heinsberg. Source: own illustration
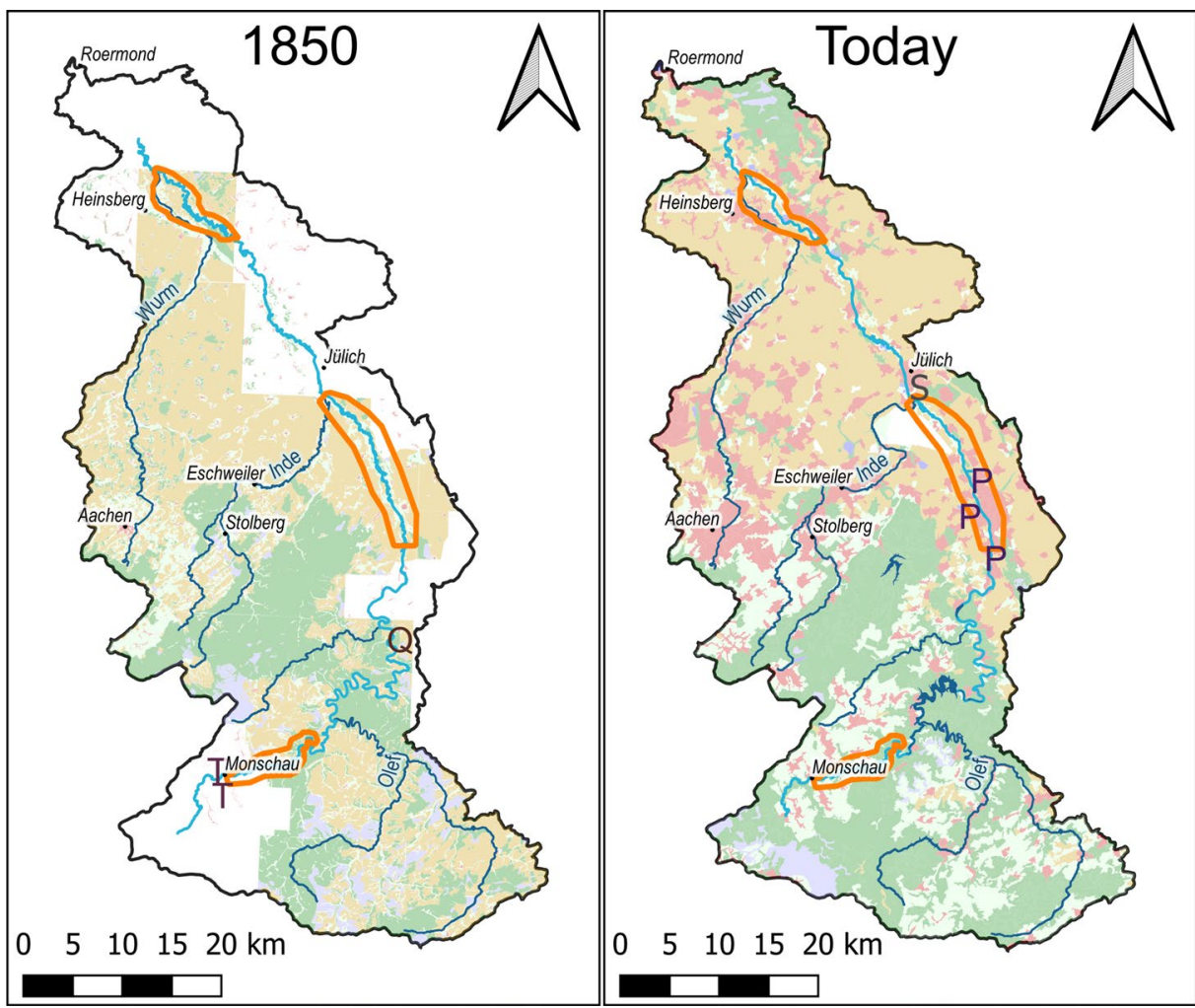

\begin{tabular}{|l|l|}
\hline Legend \\
\hline Focus Regions \\
\hline Town \\
\hline Rur River \\
Tributaries \\
Rur Dam \\
$\mathrm{P}$ & Paper Industry \\
$\mathrm{Q}$ & Quarry \\
$\mathrm{T}$ & Textile Industry \\
$\mathrm{S}$ & Sugar Factory \\
Corine Land Use \\
Agriculture \\
Urban \\
Grassland \\
Heathland \\
Forest
\end{tabular}

Fig. 7 Development of industry and land use in the Rur catchment from 1850 to today; source: own illustration; river system and catchment area: [137, 138]; towns: [139]; Corine land use data: [77, 141]

Map sheets that were previously georeferenced by the Cologne District Council were used. Therefore, information on accuracy and rectification errors cannot be given. However, since the analyses are based on quantitative data, for the purpose of this paper, an accurate cutoff of the focus regions in the various maps is more important than the accuracy of the georeferencing. To ensure that the focus regions in all time slices included identical river sections, their start points and end points were defined with the help of historic monuments and tributaries, which can be found in all historical maps and orthophotos. Details on the pixel size and scale of different maps are shown in Table 2.

\section{Digitalization of river courses and resolution}

River courses are digitalized manually with QGIS as line objects approximating the middle line of the riverbed. 
Table 2 Information regarding the pixel size and scale of the different maps used in this study

\begin{tabular}{|c|c|c|c|c|}
\hline Map & Year of origin & $\begin{array}{l}\text { Size of } 1 \text { pixel } \\
{[\mathrm{m} \times \mathrm{m}]}\end{array}$ & Scale & Techniques \\
\hline Tranchot & $1801-1828$ & $1.5 \times 1.5$ & $1: 25.000$ & Hand sketched \\
\hline Uraufnahme & $1836-1850$ & $1.5 \times 1.5$ & $1: 25.000$ & Hand sketched \\
\hline Neuaufnahme & $1891-1912$ & $1.5 \times 1.5$ & $1: 25.000$ & $\begin{array}{l}\text { Chalcography and lithographic } \\
\text { limestone; first and topographic } \\
\text { map }\end{array}$ \\
\hline TK1937 & 1936-1945 & $1.5 \times 1.5$ & $1: 25.000$ & / \\
\hline DOP1998 & 1998 & $0.3 \times 0.3$ & / & Photogrammetric methods \\
\hline DOP2003 & 2003 & $0.3 \times 0.3$ & / & Photogrammetric methods \\
\hline DOP2010 & 2010 & $0.2 \times 0.2$ & / & Photogrammetric methods \\
\hline DOP2013 & 2013 & $0.2 \times 0.2$ & / & Photogrammetric methods \\
\hline DOP2016 & 2016 & $0.1 \times 0.1$ & / & Photogrammetric methods \\
\hline DOP2019 & 2019 & $0.1 \times 0.1$ & / & Photogrammetric methods \\
\hline
\end{tabular}

Quality parameters for the accuracy of digitalization were introduced to make the length of the digitalized river courses comparable. The accuracy of a line object can be identified by its number of knots per length. Adding more knots leads to a better approximation of curved elements, but elongates the total length. With the criterion of 4 knots per $100 \mathrm{~m}$, river course comparability is ensured. The consistent distribution of knots is controlled visually using the distance matrix function. For straightened river segments, a coarser resolution is sufficient, whereas highly sinuous segments need more knots for an adequate approximation.

Additionally, morphodynamic structural elements of the Rur River are digitalized, which serve as indicators for morphodynamic activity and river straightening (cf. Fig. 8). For this study, islands in the riverbed that are not part of a braided river section are digitalized as islands. They can quickly obtain vegetation [66] and are more permanent than bars [81]. Large islands that divide the channel into two approximately equal anabranches, causing the river corridor to widen, are not marked as islands but as anastomosing channels. Anastomosing channels are multithread channels in which the outflow is divided into a multitude of watercourses [59]. Braided channel structures are characterized by intertwined blurred shorelines and variable bedload deposits in the riverbed [59]. Braid bars are not vegetated [82]. Although anabranching channels can be braided [81], in this study, braided single-channel rivers and anabranching rivers are distinguished [83]. Oxbows are either permanently connected to the watercourse or separated former river sections [84], and hence are constantly or temporarily flowing through former watercourses [84]. Side arms are permanently flowing side waters, whose start and end are attached to the main course. Side arms differ

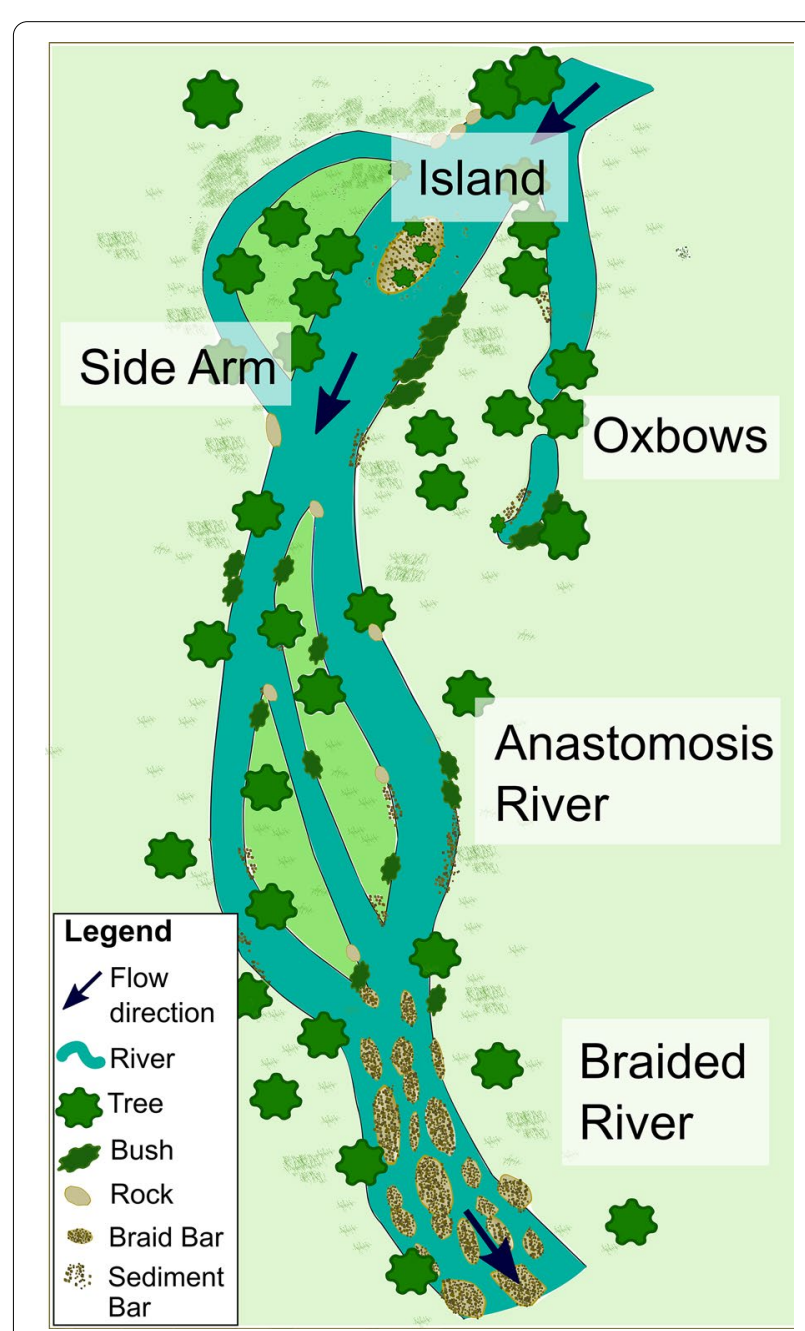

Fig. 8 Objects of digitalized river courses. Source: own illustration; criteria according to $[59,83,84]$ 
Table 3 Decision matrix for digitalizing structural elements

\begin{tabular}{|c|c|c|c|c|c|c|c|c|}
\hline \multicolumn{7}{|l|}{ Characteristics } & \multirow[t]{3}{*}{ Structure } & \multirow{3}{*}{$\begin{array}{l}\text { (possible) } \\
\text { Alternative }\end{array}$} \\
\hline \multicolumn{3}{|l|}{ Channel } & \multirow{2}{*}{$\begin{array}{l}\text { River corridor } \\
\text { Widening }\end{array}$} & \multicolumn{3}{|l|}{ Island(s) } & & \\
\hline No. of channels & Enlarged & $\begin{array}{l}\text { Flow } \\
\text { distribution }\end{array}$ & & Size & Number & Vegetated & & \\
\hline \multirow[t]{3}{*}{1} & Yes & - & No & Small & More than 1 & No & Braided river & Island \\
\hline & Maybe & - & No & Small to medium & 1 & No & Island & $\begin{array}{l}\text { Braided river } \\
\text { (beginning/ } \\
\text { end of sec- } \\
\text { tion) }\end{array}$ \\
\hline & No & - & No & & & Maybe & Island & \\
\hline 1 or 2 & Yes & - & Maybe & Medium to large & 1 & Yes & Island & $\begin{array}{l}\text { Anastomosing } \\
\text { river }\end{array}$ \\
\hline \multirow[t]{2}{*}{ More than 1} & Yes & Evenly & Maybe & Medium to large & 1 or more & Yes & $\begin{array}{l}\text { Anastomosing } \\
\text { river }\end{array}$ & Island(S) \\
\hline & & & Yes & Large & 1 or more & Yes & $\begin{array}{l}\text { Anastomosing } \\
\text { river }\end{array}$ & \\
\hline \multirow[t]{2}{*}{2} & - & Uneven & Yes & Large & 1 & Yes & Side arm & $\begin{array}{l}\text { Anastomosing } \\
\text { river }\end{array}$ \\
\hline & & Definitely uneven & Yes & Large & 1 & Yes & Side arm & \\
\hline
\end{tabular}

Table 4 Morphologic indicators for channel changes and their meaning

\begin{tabular}{|c|c|c|}
\hline Indicator & Description & Meaning \\
\hline Change in total river length & $\begin{array}{l}\text { Total river length of the Rur River in a focus region } \\
\text { compared to today's river length, estimated from the } \\
\text { DOP } 2019\end{array}$ & $\begin{array}{l}\text { Decrease in the river length is a sign for artificial } \\
\text { straightening [87] }\end{array}$ \\
\hline Sinuosity & $\begin{array}{l}\text { Total river length of the Rur River in a focus region } \\
\text { divided by the thalweg [88-92], computed with the } \\
\text { DEM } 25\end{array}$ & $\begin{array}{l}\text { Reduced sinuosity often is a sign for river straighten- } \\
\text { ing }[54,93] \text {, an increase is a sign for tending towards } \\
\text { a new equilibrium [87] but can also occur when the } \\
\text { flow velocity increases [55] }\end{array}$ \\
\hline Relative length of channel structures & $\begin{array}{l}\text { Total length of channel structures in a focus region } \\
\text { divided by the river length in the focus region }\end{array}$ & $\begin{array}{l}\text { An increase in the channel structures is a reaction to } \\
\text { changes in the sediment load and/or changes in the } \\
\text { river slope [87], often due to straightening [94] }\end{array}$ \\
\hline Anastomosing channel & For anastomosing channels & $\begin{array}{l}\text { Anabranching rivers are often caused by flood-domi- } \\
\text { nated flow regimes }[63,83]\end{array}$ \\
\hline Braided channel & For braided river structures in single channels & $\begin{array}{l}\text { Sign for excess bedload, coarse bottom substrate and } \\
\text { high valley bottom slope }[57,95], \text { instable state [96] }\end{array}$ \\
\hline Side arm & For side arms & $\begin{array}{l}\text { Occur at flood events as a reaction to hydraulic stress; } \\
\text { today side arms are preserved as habitats [97] }\end{array}$ \\
\hline Relative of number oxbows & $\begin{array}{l}\text { Number of oxbows in a focus region divided by the } \\
\text { river length in } \mathrm{km}\end{array}$ & $\begin{array}{l}\text { Oxbows as channel cut-offs are a sign for river course } \\
\text { shortening [55] }\end{array}$ \\
\hline Relative number of islands & $\begin{array}{l}\text { Number of islands in a focus region divided by the river } \\
\text { length in } \mathrm{km}\end{array}$ & $\begin{array}{l}\text { Changes in islands indicate recent flood events, island } \\
\text { formation is a sign for coarse sediment input [55] }\end{array}$ \\
\hline
\end{tabular}

DEM25 digital elevation model with a grid resolution of $25 \mathrm{~m}, D O P$ digital orthophoto

from anabranches since they are smaller than the main channel.

Hand-sketched historic maps at a low resolution and vegetation in digital orthophotos lead to difficulties in digitalization, as also recognized by Roccati et al. [85]. The transition between islands and short sections of single braided channel or two anastomosing channel structures is fluent. Therefore, some structural elements are digitalized with a possible alternative (cf. Table 3.).

For the analysis, the first choice for the type of structural element is considered with a weight of 0.8 , and the alternative is considered with a weight of 0.2 . From the digitalized channels and its structural elements, indicators are computed for each time slice according to Table 4. Inaccuracies reaching $20 \mathrm{~m}$ in historical maps of 
the nineteenth century lead to a variation in the results of less than $0.2 \%$. Focus regions are not affected by sheet lines or map edges. Therefore, the results can be specified without an error range.

Computing the change in the total river length of the Rur River in the three focus regions, today's river length is compared to the corresponding length from historic maps or orthophotos. A change of 0.0 means that the total river length has not changed in comparison to 2019, whereby a change of 0.1 means that the river course has been $10 \%$ longer in a previous time slice compared to today. A change of -0.1 means that the river course was $10 \%$ shorter in previous times. With this normalized approach, focus regions can be compared with each other in addition to covering unequally long river sections.

To calculate the river sinuosity, the thalweg for each focus region is computed using a digital elevation model (DEM) with a grid resolution of $25 \mathrm{~m}$ (DEM25). By using a relatively coarse DEM, it is ensured that the thalweg and not the river coarse is computed (e.g., [86]).

Indicators are used to evaluate the development of river straightening (Eq. 1). Additionally, whether the structural diversity of rivers is increasing is evaluated (Eq. 2). If structural development is driven by fluvial processes it is very likely self-sustaining [98].

The increase in river straightening between two time slices is defined as:

$$
\Delta_{\text {Straightening }}=-\Delta_{\text {Sinuosity }}+\Delta_{\text {Braiding }}+\Delta_{\text {Oxbows }},
$$

with $\Delta_{\text {Sinuosity }}$ as the change in sinuosity between two time slices, indicator for river straightening according to $[54,58,93] ; \Delta_{\text {Braiding }}$ as the change in length of braided channel sections between two time slices, indicator for river straightening according to $[58,63,95]$; and $\Delta_{\text {Oxbows }}$ as the change in the number of oxbows between two time slices, indicator for river straightening according to [55].

The increase in structural diversity between two time slices is defined as:

$$
\Delta_{\text {Structural Diversity }}=\Delta_{\text {Side Arms }}+\Delta_{\text {Anastomosing }}+\Delta_{\text {Islands }},
$$

with $\Delta_{\text {Side Arms }}$ as the change in length of side arms between two time slices, indicator for river straightening according to [97]; $\Delta_{\text {Anastomosing }}$ as the change in length of anastomosing channels between two time slices, indicator for river straightening according to [63]; and $\Delta_{\text {Islands }}$ as the change in the number of islands between two time slices, indicator for river straightening according to [55].

To evaluate whether the Rur River experienced significant straightening during the Industrial Phase (2), the

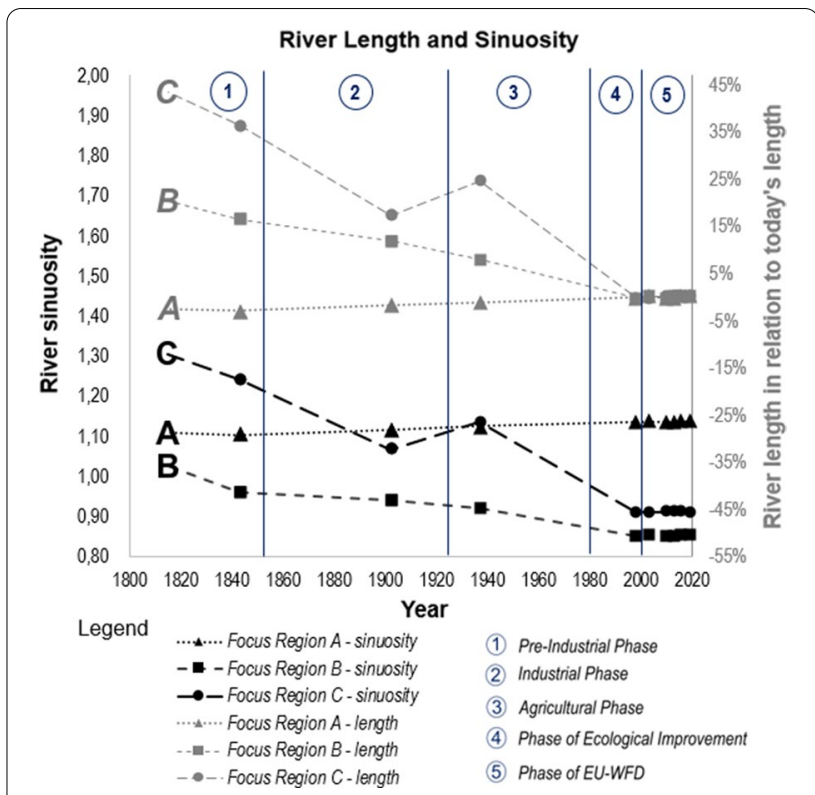

Fig. 9 Changes in river length and sinuosity in the three focus regions of the Rur River over its five phases of river management in the last 200 years. Source: own illustration

increase in river straightening (Eq. 1) is evaluated in each of the five phases. A positive value means, that the river has experienced straightening during a specific period. A negative value means, that straight river sections have been reduced. Additionally, one assumes an increase in structural diversity in the Phase of EU-WFD (5). Therefore, as a second outcome value, the increase or decrease in structural diversity within the five phases is evaluated.

\section{Results}

First, changes in river length and sinuosity in the three focus regions are evaluated. In focus region $A$, the river course was $2.6 \%$ shorter in the early nineteenth century compared to today, meaning that a small river elongation has occurred (cf. Fig. 9). The river section elongated from 14.44 to $14.82 \mathrm{~km}$. In focus region $\mathrm{B}$, a river course shortening of approximately $20 \%$ has occurred during the same time period. The length of the river section changed from 23.08 to $19.20 \mathrm{~km}$ between the early nineteenth century and 2019. In focus region C, the largest river course shortening of approximately $43 \%$ has occurred since the early nineteenth century. Here, the length of the river section changed from 19.05 to $13.29 \mathrm{~km}$. Since the twenty-first century, the length of the river courses has remained static in all three focus regions.

Overall, the total river length changed the least in focus region $\mathrm{A}$ in the low mountain area. In the lowlands, greater changes in total river length occurred, whereby the greatest change occurred in focus region $C$, where 
the Rur River is categorized as a gravel-embossed lowland river.

The sinuosity in focus region A slightly increased from 1.11 to 1.14 over the last 200 years (cf. Fig. 9). According to the criteria of Brice [92], the Rur River in focus region A is classified as sinuous in all five phases. In focus region $\mathrm{B}$, the sinuosity dropped from 1.02 to 0.85 , meaning that the main course of the river is shorter than the thalweg

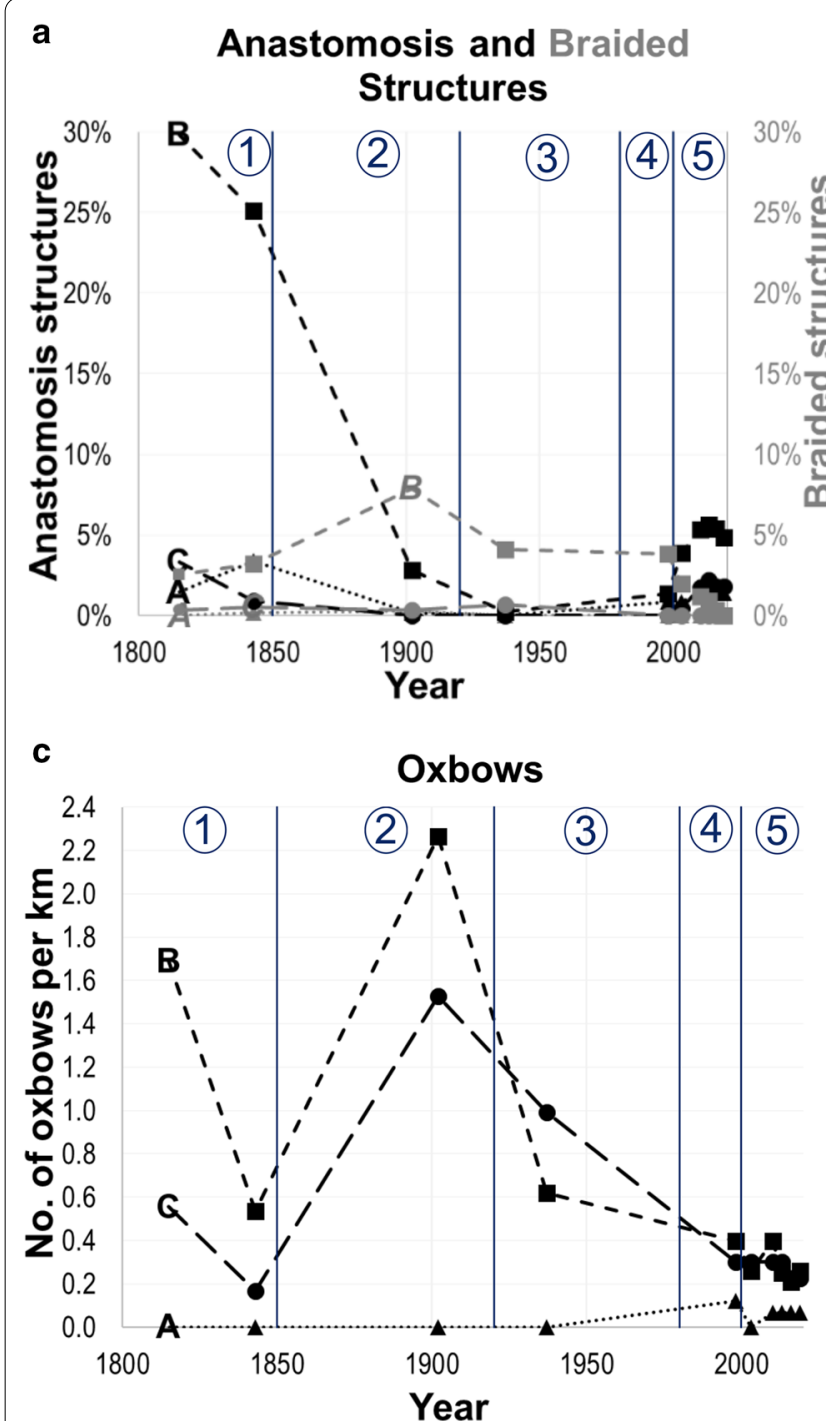

Legend

...... Indicator in Focus Region $A$

- - Indicator in Focus Region $B$

$\longrightarrow$ - Indicator in Focus Region C

\section{Start/End of Phases}

b

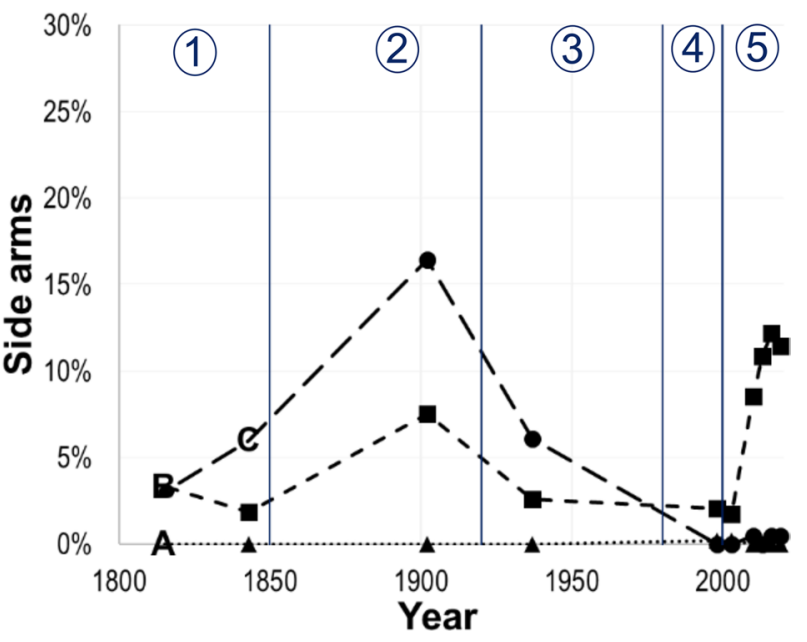

d

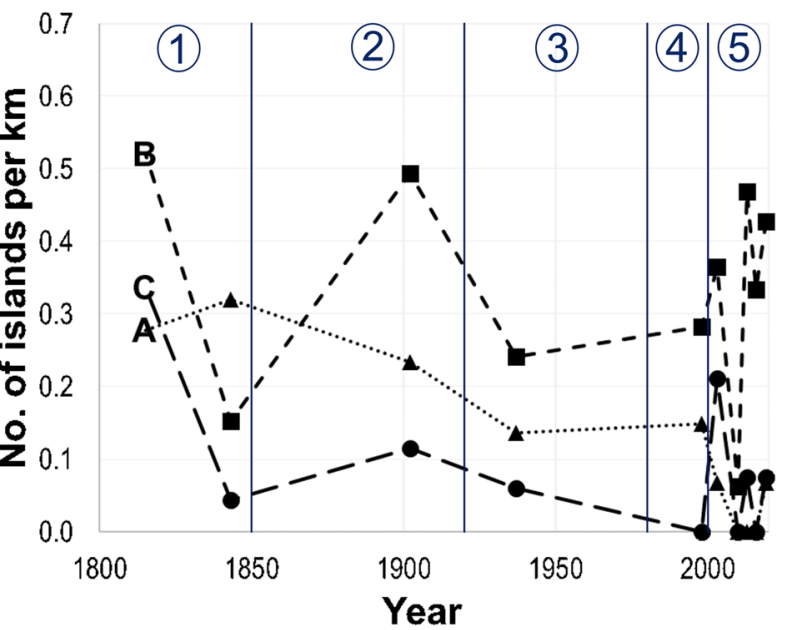

(1) Pre-Industrial Phase

(2) Industrial Phase

(3) Agricultural Phase

(4) Phase of Ecological Improvement

(5) Phase of EU-WFD

Fig. 10 Change in indicators over the five phases of river management in the last 200 years in the three focus regions of the Rur River, a changes in the length of anastomosing and braided river structures in comparison to the total river length, $\mathbf{b}$ changes in the length of side arms in comparison to the total river length, c) changes in the average number of oxbows per river-km, and $\mathbf{d}$ changes in the average number of islands per river-km.

Source: own illustration 
predicted by the DEM25. The largest decreases in sinuosity occurred during the Pre-industrial (1) and Agricultural (3) Phases. With a sinuosity smaller than 1.06, the Rur River in focus region $B$ has been straight over the last 200 years [92]. The Rur River in focus region $C$ changed its sinuosity from 1.30 to 0.91 . Therefore, the river course changed from meandering to straight [92]. Since the early twenty-first century, river sinuosities have stabilized with a very slight tendency to increase.

Braided channels only occur in small areas, whereby anastomosing channels can be found more often (cf. Fig. 10a). In the Pre-industrial Phase (1), the length of anastomosing channels increased from 1.5\% (approx. $0.2 \mathrm{~km}$ of additional channel length) of the total river length in focus region A to 3.5\% (approx. $0.5 \mathrm{~km}$ ). During the Industrial Phase (2), anastomosing channels almost vanished (approx. $0.03 \mathrm{~km}$ ), but some braided river structures occurred (approx. 0.04 km). Since the Phase of EUWFD (5), anastomosing channels are expanding again (back to approx. $0.2 \mathrm{~km}$ ). In focus region B, anastomosing channels had significant lengths during the Pre-industrial Phase (1) (approx. $6.9 \mathrm{~km}$ ). During Phase 2, the length of the additional channel declined to approx. $0.6 \mathrm{~km}$. However, braided channel sections were at their longest, with approx. $1.7 \mathrm{~km}$. Since the Agricultural Phase (3), anastomosing channels have expanded slightly (approximately $1 \mathrm{~km}$ of additional channel length), and since the early twenty-first century, braided channel sections have disappeared again.

Side arms are not present in focus region A, which can be explained by the steep thalweg (cf. Fig. 10b). Only one anastomosing channel is digitalized with a "side arm" as an alternative in early orthophotos (1998 and 2003). Later, a third channel occurs, marking the section as an anastomosing river. Due to dense vegetation, the channel width cannot be determined. In focus region $B$, the total length of the side arms decreased during the Industrial Phase (2) from $>1$ to $0.6 \mathrm{~km}$. Today, side arms total approximately $2 \mathrm{~km}$ in focus region B. In focus region C, side arms were of significant length during Phase 2 . Four side arms had a total length of approximately $2.6 \mathrm{~km}$. Today, only one anastomosing structure is digitalized with a "side arm" as an alternative.

In focus region A, oxbows rarely occur, with less than one oxbow per river-km; however, they increased in the late twentieth century, when two small oxbows occurred (cf. Fig. 10 c). In focus region B, oxbows occur more often. In the nineteenth century, 12 to 48 oxbows were counted in hand-sketched maps. After Phase 2, the number of oxbows per $\mathrm{km}$ dropped from approximately 2.0 to 0.5 with a decreasing tendency to the present. Since the twenty-first century, approximately five oxbows have been counted in orthophotos. In focus region $\mathrm{C}$, a maximum of 24 oxbows occurred in Phase 2. Afterwards, numbers have been declining, reaching three oxbows today.

Overall, the number of islands per river-km has decreased in the last 200 years in focus region A from four to one island (cf. Fig. 10d). In focus region B, the average number of islands varies heavily between 12 islands (map of Tranchot) and one island (DOP2010). After a decrease in islands during Phase 1 in focus region $C$ from six to two, the number of islands stayed low. In focus region $\mathrm{C}$, between three and one islands were counted in the first topographical map and orthophotos.

The greatest changes in river sinuosity occur at the Rur River in focus region $\mathrm{C}$ during Phases 2 and 3 (cf. Fig. 11). In focus region $B$, the decrease in river sinuosity is almost as significant as that in focus region $\mathrm{C}$. The largest changes in braided and anastomosing channel sections occur in focus region B. During Phases 1 and 2 , anastomosing channels decreased and braided river structures increased. During Phase 3, both braided and anastomosing channels as well as the sinuosity of the Rur River decreased in focus region $B$. The number of oxbows greatly varied during Phase 1 , Phase 2 and Phase 3 in focus regions $B$ and $C$. Additionally, the number of islands varied during this time, but for both indicators, a significant increase during the Industrial Phase (2) can be observed. Since the general focus shifted towards improving the water quality and sustainability in river management (Phases 4 and 5), the number of oxbows slightly decreased and the number of islands slightly increased in focus region $\mathrm{B}$, whereas both small-scale indicators decreased in focus region $\mathrm{C}$.

With these indicators (cf. Fig. 11), using equations I and II, the development of river straightening and structural diversity in the five phases of river management can be evaluated (cf. Fig. 12). In contrast to the other two focus regions, no river straightening is observed in focus region A. Additionally, changes in structural diversity are very small in focus region A. In the Pre-industrial Phase (1), river straightening and structural diversity decreased in focus region B and increased in focus Region A. During the Industrial Phase (2), both river straightening and structural diversity increased in focus regions $B$ and $\mathrm{C}$, which are both located in the lowlands of the Rur catchment.

During the Agricultural Phase (3), developments were similar to those in the Pre-industrial Phase, except structural diversity further decreased. Since the 1980s [Phase of Ecological Improvement (4) and Phase of EU-WFD (5)], river straightening has decreased, but structural diversity has only increased for focus region $\mathrm{B}$.

The Rur River was only regulated in small local sections before 1950 [99]. Between 1962 and 1970, larger sections 


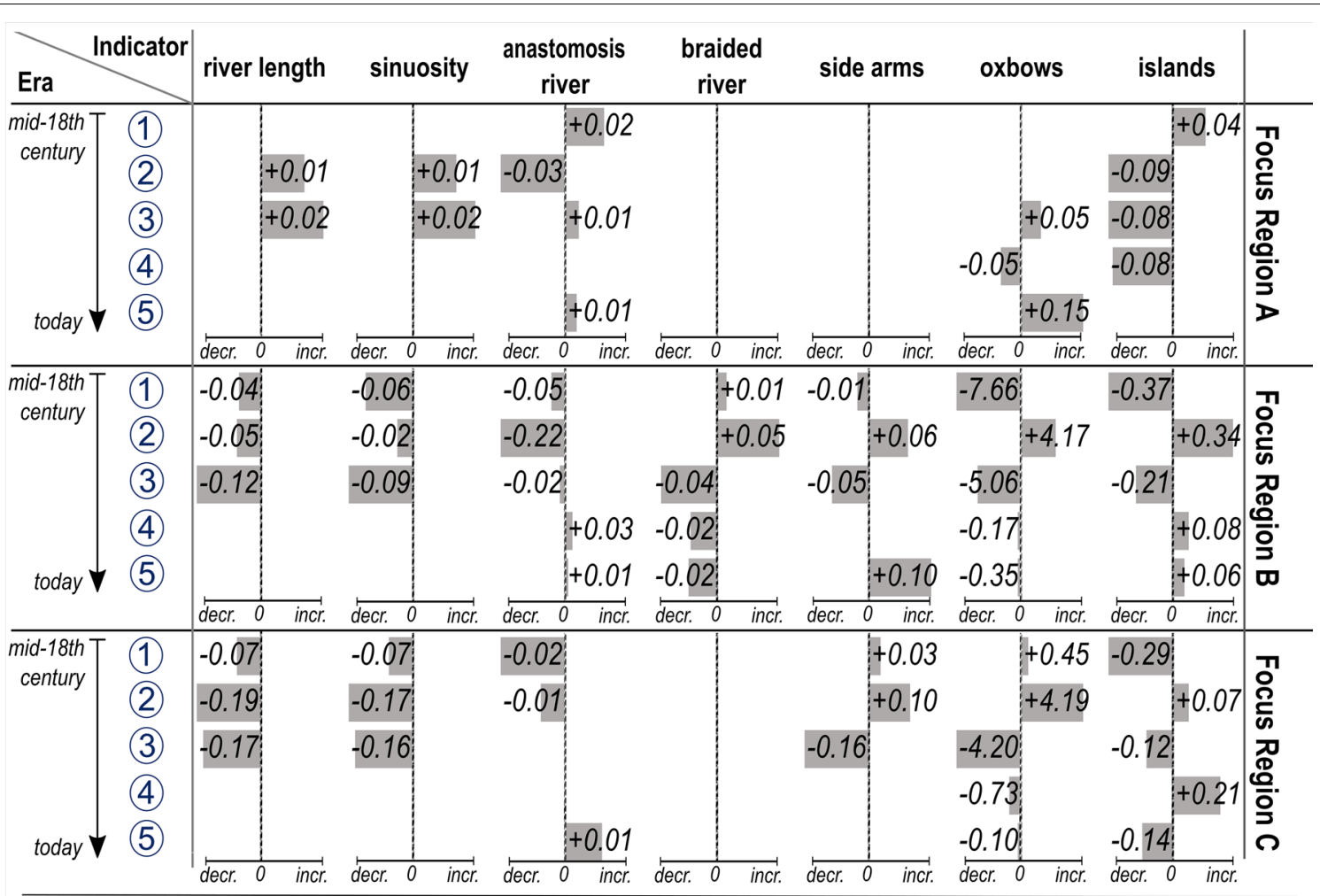

Legend

(1)Pre-Industrial Phase (2)Industrial Phase (3)Agricultural Phase (4)Phase of Ecological Improvement (5)Phase of EU-WFD

Fig. 11 Development of indicators for morphodynamic activity and river straightening in the three focus regions over the five phases of water management in the last 200 years. Source: own illustration

from Düren to Heinsberg were channelized, leading to an artificial shortening of the river course [42, 100].

\section{Discussion}

The results show the development of river length, sinuosity and morphodynamic indicators over five phases of river management during the last 200 years. River length and sinuosity are direct indicators of river straightening. However, the validity of indicators derived from morphodynamic structural elements needs to be discussed, since they are dependent on geological and climatic factors and river type.

\section{River development in the Rur catchment River straightening}

In comparison to focus region $\mathrm{A}$ in the low mountainous area, focus regions $B$ and $C$ in the lowlands experienced significantly more changes over the last 200 years (cf. Fig 13e). River straightening, which leads to channel shortening, is often connected with land reclamation for agricultural activities. A study from Brookes shows that river straightening is less likely to be used when valleys are too steep for farmland [87], as is the case in the low mountainous area of focus region A. In addition, the small changes in sinuosity and river braiding in focus region $A$ in comparison to focus regions $B$ and $C$ indicate that the narrow valleys lead to a more stable river morphology [82, 101].

Changes in sinuosity from 1.02 to 0.85 in focus region $\mathrm{B}$, which is characterized by farmland, indicate that the river has experienced artificial straightening. During the Pre-industrial Phase (1), the river length in focus region B significantly decreased, although river regulation works started more than 100 years later [99]. This leads to the theory, that intense agricultural activities to make fertile floodplains usable and reduce flooding led to river straightening during this phase. In addition to agriculture, local riverbed straightening around bridges is common [102], which means that an expanding infrastructure leads to river straightening. A considerable expansion of industrial and urban settlements in focus region B (cf. Fig. 6) is another explanation for river straightening in this area. 

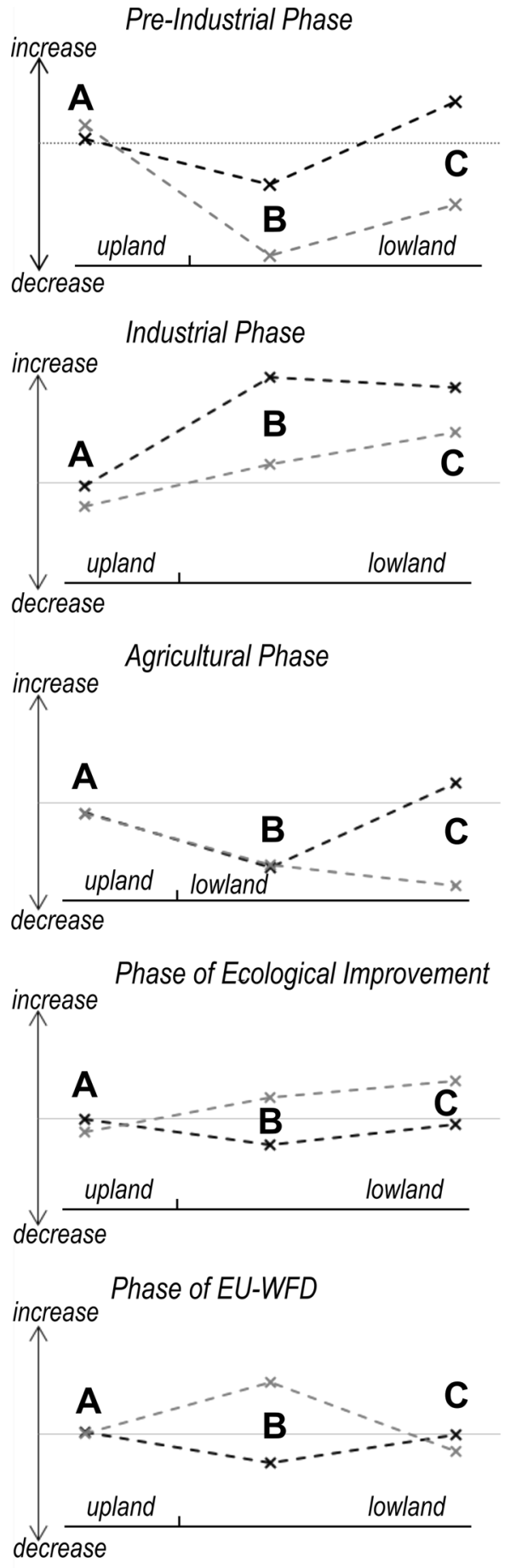

Legend

- - - River Straightening- - - - -Structural Diversity

A B C Focus Regions

Fig. 12 Qualitative development of all indicators for river straightening and natural morphological activity after the five historical phases of the last 200 years. Source: own illustration
With a decreasing sinuosity and assuming an increase in oxbow and braided river structures are signs of river straightening, the Industrial Phase straightened the river. In addition, structural changes over large areas for agriculture led to river straightening in the lowlands. Some of these changes can be explained by largescale river regulation between 1962 and 1970 in the middle and lower reaches $[42,100]$.

\section{Structural diversity}

During the Industrial Phase (2), the number of islands increased, which can be explained by a higher sediment yield due to land clearance and deforestation for uprising industries [42]. The significant drop in islands during Agricultural Phase (3) in focus regions B and C can be explained by dam construction in the twentieth century and the resulting regulation of discharge in the Rur River. In particular, the systems of three dams, as they are installed in the Rur River, can trap nearly all inflowing sediments [103]. In addition, the land use change, which was connected with land reclamation, explains the decrease in side arms and oxbows during the Agricultural Phase (3) in focus regions B and C (cf. Fig. 13). Since the general focus shifted towards improving the water quality and sustainability in river management in the late twentieth century, the number of oxbows slightly decreased and the number of islands slightly increased in focus region $B$, whereas both small-scale indicators decreased in focus region C. Regarding the Agricultural Phase within the Technological Era according to [19] one needs to keep in mind that in the early Anthropocene, land consumption for farming was considerably higher [104]. Hence, morphodynamic changes in the Agricultural Phase according to this study very likely intensified during the early Anthropocene.

In the twentieth century, the reduction in baseflow levels due to the installation of hydroelectric power plants in many rivers led to the siltation of many side arms [105]. In addition, the increasing urbanization from the twentieth century onwards has also led to increased sediment inputs into the waters at the beginning of urbanization due to land plot clearing [93]. If urban structures are largely developed, the sediment input is reduced again, but the hydrological retention of the area is greatly reduced [93]. At the end of the twentieth century, restoration of side arms began to create habitats [105].

Contrary to expectations, structural diversity does not increase significantly in the Phase of EU-WFD (5). On the one hand the Phase of Ecological Improvement and the Phase of EU-WFD are much shorter than previous ones, and therefore, the river has less time to develop. On the other hand, human interference on the Rur River changed key drivers such as hydrology through damming and land 


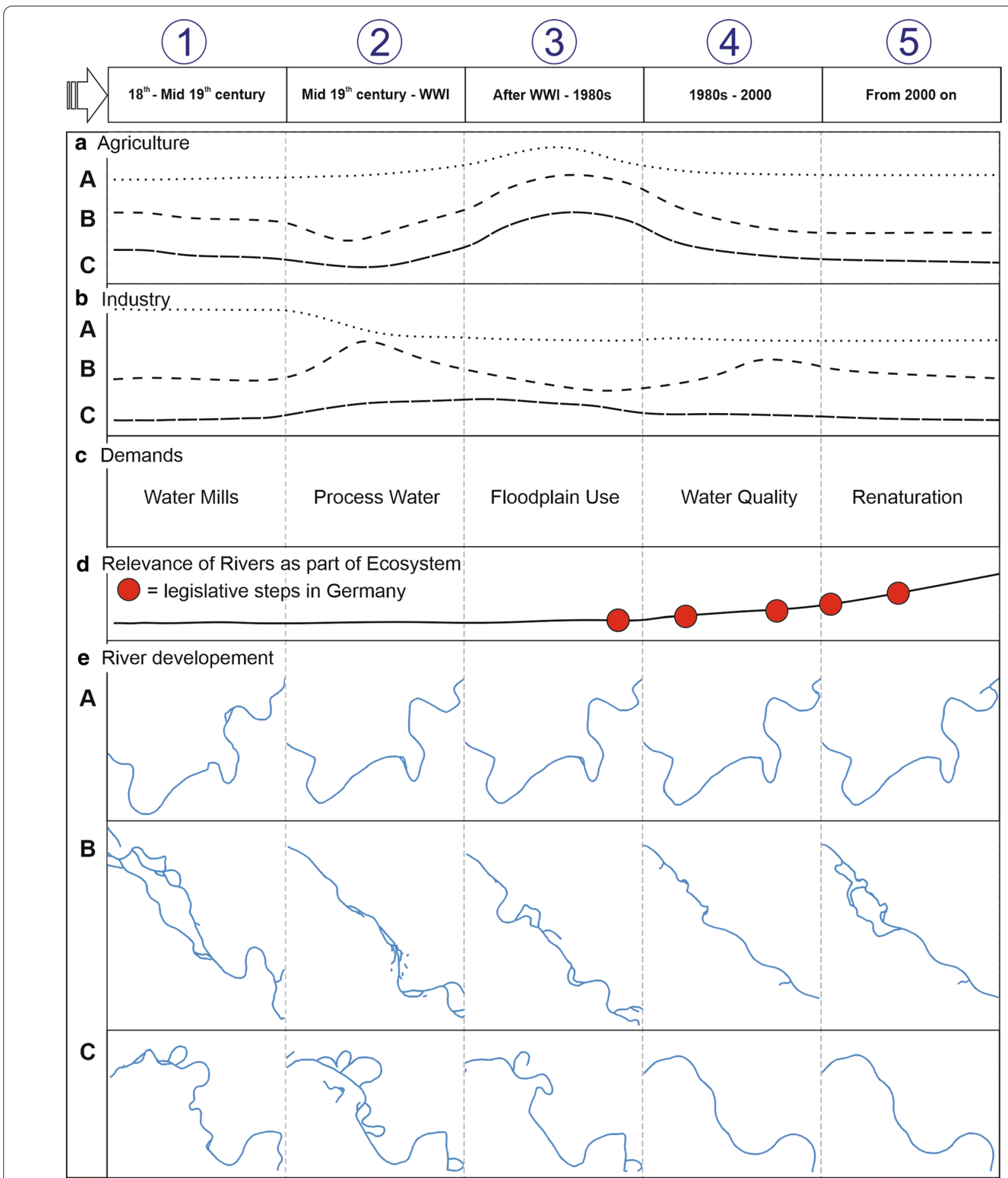

Fig. 13 Changes in river courses in the three focus regions of the Rur River over the five phases of water management in the last 200 years. a development of agricultural use of floodplains in the three focus regions, $\mathbf{b}$ development of industrial use of floodplains in the three focus regions, $\mathbf{c}$ main demand in the different phases of water management, $\mathbf{d}$ amendment of the German Federal Water Act, and e river course development of a representative section of the focus regions. Source: own illustration

use. Geology, biology and hydrology can be considered key drivers of river morphodynamics [101]. These drivers balance each other, which explains why anabranching channels are stabilized by vegetation, jet hydrology has only a minor impact, and braided river sections are not influenced by vegetation but rather by high stream power 
$[101,106]$. When a key driver is anthropogenically overpronounced, natural river recovery will be slow unless the impact can be balanced through (artificial) river restoration [101]. Filling incised channels or reintroducing the establishment of protected areas for beavers are two examples of countervailing measures $[3,101]$ restoring "wilder" river sections. For the last two decades, beavers have repopulated northwest Germany [107]. The repopulation of beavers in the Rur catchment is carried out and accompanied by local institutions. Today, numerous beavers are again living on the Rur River and especially on its tributaries [108]. Nevertheless, the analysis of orthophotos did not show evidence for these animals in the focus regions, and morphodynamic effects of the beaver population could not be observed in this work. Regardless, the repopulation holds chances for future river development [109]. Today, "controlled rewilding" on suitable river sections is promoted to create valuable habitats with native vegetation [110]. In the nineteenth and twentieth centuries on the Wurm River, a main tributary of the Rur River, water mills from medieval times were abandoned [111, 112]. When abandoned weirs were partially removed, mill ditches were left to "rewild" [111]. This phase of "natural rewilding" was very local and soon superimposed by institutional river regulation. Thus, we expect that "controlled" or "natural rewilding" will be used for river restoration in the future. Future studies should be conducted to determine the effects of rewilding on river morphology.

\section{European transferability of the concept of the five phases of river management}

To transfer the findings to other river systems, the transferability of the five phases of river management, which apply to the Rur catchment, needs to be discussed. Therefore, the five phases of river management in the Rur catchment are compared to the history in catchments with increasingly strong industrial development in the last 200 years. Furthermore, findings from recent GISbased studies of anthropogenically influenced development on rivers in the Technological Era are compared to this study to find generalities.

Generally, the period from the late eighteenth century to World War I is declared a phase of European industrialization, but the growth rate varies greatly between different countries [113]. Around the fourth to fifth decades of the nineteenth century, the phase of economic preparation was completed for countries in middle Europe, and their industrial development sped up [113]. River straightening and the increase in structural diversity on the Rur River are explained by the catchment-specific development of the last 200 years.
In Poland, a preparation phase for industrialization took place in the mid-nineteenth century [114], approximately 100 years behind the development in the Rur catchment. The landscape of the Vistula catchment has been influenced since the thirteenth century through water mills and settlements [17]. Over the last 200 years, landscape changes, differences in the use of process water and drainage, as well as the construction of infrastructure have impacted the development of the Vistula River [17]. Since the early twentieth century, river channelization and straightening for shipping have intensified in Poland [115]. Similar to the Rur catchment, the Skawa River was not channelized for navigation, but industrialization led to irreversible changes in river morphology [116]. After World War II, industrial development in Poland sped up, so the last 75 years can be viewed as the main part of the Industrial Phase [114]. Additionally, the demand for process water was still growing 25 years ago [117]. In Poland, industrial development is accompanied by the construction of small water mills as local and independent energy sources [118]. After intense river straightening on river systems in northern Poland in the last century, the water quality decreased [119]. Since the early twenty-first century, the situation has improved due to oxbow and old arm restoration and its maintenance [119]. This development is comparable to the Phase of Ecological Improvement and the Phase of EU-WFD in the Rur catchment.

For the Skawa River, which is a mountain tributary of the Vistula River, five digitalized maps from the midnineteenth century to 2016 were evaluated to explain the human impact on the river [116]. Similar to the Rur River in its upper reach, the Skawa River is a gravelly embossed river [116]. Witkowski evaluated sinuosity, the braiding and anastomosing index, as well as the average number of mid-channel forms and the average distance of the outer banks of the river channel [116]. Although indicators and proceedings slightly differ from the present study, the findings are very comparable. In the early twentieth century, agriculture and settlements in the floodplain of the Skawa River led to the construction of embankments [116]. Between 1864 and 1911, islands decreased, and the bed narrowed, meaning that anastomosing structures decreased [116]. On the Rur River, a drop in islands also correlates with increasing settlements and agriculture in the floodplains (cf. Figure 10). In the mid-twentieth century, the riverbed of the Skawa River was completely channelized [116]. Since the twenty-first century, more anabranching structures have occurred, and sinuosity has increased again after the removal of riverbank protections on the Skawa River [116]. The channel width has increased since the late 1970s. These developments overlap with the Phase of Ecological Improvement and the Phase of EU-WFD of the Rur River. 
This means that the anthropogenic influence on the rivers is slowly adapting overall between European countries in moderate climatic zones. In summary, the examples show that the development of river management in the last 200 years is comparable in Europe.

\section{Worldwide context}

Common anthropogenic drivers of morphological changes in rivers worldwide are land cover and land use changes, dam construction, bank protection and instream mining [120]. In the early days of Industrial Phase small-scale water mills were an important energy source [121]. During the peak time of the Industrial Phase, rivers played a primary role in transportation, which led to the building of various canals [122-124]. Over the past 150 years, the Mississippi River has been straightened mostly for navigation $[66,125]$. At the same time, navigable canals in France extended [58]. In England in the early nineteenth century, canals expanded, providing a cheap way to transport coal [126]. The Rhine, Rhône and Danube Rivers were also channelized in the nineteenth century [127]. Swedish hydropower developed after World War I for industrial purposes, which led to river regulation [128].

Although the Rur River was not channelized for shipment, it straightened during the Industrial Revolution. Therefore, in industrialization periods, the impact of human activities straightens rivers, either by direct channel construction or by overall anthropogenic influences on the river.

Large river course structures such as anastomosing structures are not dependent on a certain climate type [63], so it can be assumed that river straightening during an industrial phase occurs independently from climate conditions and discharge regime. Nevertheless, valley configurations, base slope and sediment input are important for the formation of structures, such as braided and anastomosing sections and islands.

\section{Conclusions}

In this study, the specific human impact of different time periods on river courses during the last 200 years is investigated using the example of the Rur River (Germany, North Rhine-Westphalia), which is a typical European upland-to-lowland river.

Five historic phases of industrial development between 1801 and 2019 can be distinguished:

1. Pre-industrial Phase (mid-eighteenth to mid-nineteenth century)

2. Industrial Phase (mid-nineteenth century to WWI)

3. Agricultural Phase (after WWI to 1980s)

4. Phase of Ecological Improvement (1980s to 2000)

\section{Phase of EU-WFD (from 2000 to the present).}

These phases correlate with changes in the river course, which can be explained by corresponding human interventions. The changes are detected by means of the following morphodynamic indicators sinuosity, anastomosing and braided river structures, side arms, oxbows and islands. Changes in river straightening and structural diversity are determined from these indicators by two simple equations.

The morphodynamic indicators show significant differences between focus regions in the low mountain range and in the lowlands. In total, focus regions in the lowlands are more strongly characterized by changes over the last 200 years compared to focus regions in the low mountain area. In this context, the sinuosity or river braiding indicators show that the mountainous valley configurations lead to a more stable river morphology.

The Industrial Phase, in contrast to the Pre-industrial Phase, was characterized by intense river straightening, indicated by decreasing sinuosity and increasing numbers of oxbows and braided river structures. The Agricultural Phase led to river straightening in the lowlands due to land reclamation. Both the Phase of Ecological Improvement and the Phase of EU-WFD show no significant changes so far, which can be explained by the short time frame.

A combination of historical maps and digital orthophotos together with historical documents is very well suited for comparable investigations.

The comparison of historical periods in different regions generally shows a global transferability of the concept of the five river management phases. Since the different periods are to be understood as cultural epochs, their starting and ending points may vary in time and space, depending on factors such as wealth disparity or legislation. Therefore, they are still applicable to other study areas, especially in regions characterized by an earlier development stage of industrialization.

To complement this study, further research in regions with strongly differing historical frame conditions and physiographic differences is needed. The key to sustainable river management in the future is understanding the interaction between fluvial systems and human intervention in the past. Thus, the findings and the concept of this study can be used for further research and investigation.

\section{Acknowledgments \\ We sincerely thank the editor and two anonymous reviewers who improved the manuscript.}

\section{Author contributions}

SW and VE wrote the first draft of the manuscript. All authors contributed to specific aspects of the manuscript. All authors read and approved the final manuscript. 


\section{Funding}

Open Access funding enabled and organized by Projekt DEAL. This work is funded by the Deutsche Forschungsgemeinschaft (DFG) — under project number 418362535

\section{Availability of data and materials}

Not applicable.

\section{Ethics approval and consent to participate}

Not applicable.

\section{Consent for publication}

Not applicable.

\section{Competing interests}

The authors declare that they have no competing interests.

\section{Author details}

${ }^{1}$ Institute for Hydraulic Engineering and Water Resources Management, RWTH Aachen University, Mies-van-der-Rohe-Straße 17, 52056 Aachen, Germany.

${ }^{2}$ Department of Geography, RWTH Aachen University, Wüllnerstraße 5b, 52064 Aachen, Germany.

Received: 30 October 2020 Accepted: 23 January 2021

Published online: 08 February 2021

\section{References}

1. Bandyopadhyay S, De SK (2017) Introduction. In: Bandyopadhyay S, De SK (eds) Human interference on river health, vol 13. Springer International Publishing, Cham, pp 1-14

2. Scorpio V, Aucelli PPC, Giano SI et al (2015) River channel adjustments in Southern Italy over the past 150 years and implications for channel recovery. Geomorphology 251:77-90. https://doi.org/10.1016/j.geomo rph.2015.07.008

3. Brown AG, Lespez L, Sear DA et al (2018) Natural vs anthropogenic streams in Europe: History, ecology and implications for restoration, river-rewilding and riverine ecosystem services. Earth Sci Rev 180:185-205. https://doi.org/10.1016/j.earscirev.2018.02.001

4. Hoffmann T, Lang A, Dikau R (2008) Holocene river activity: analysing 14C-dated fluvial and colluvial sediments from Germany. Quatern Sci Rev 27:2031-2040. https://doi.org/10.1016/j.quascirev.2008.06.014

5. Hoffmann T, Erkens G, Gerlach R et al (2009) Trends and controls of Holocene floodplain sedimentation in the Rhine catchment. CATENA 77:96-106. https://doi.org/10.1016/j.catena.2008.09.002

6. Bork H-R (1998) Landschaftsentwicklung in Mitteleuropa: Wirkungen des Menschen auf Landschaften; 36 Tabellen, 1. Aufl. Perthes GeographieKolleg. Klett-Perthes, Gotha

7. Hoffmann T, Thorndycraft VR, Brown AG et al (2010) Human impact on fluvial regimes and sediment flux during the Holocene: review and future research agenda. Global Planet Change 72:87-98. https://doi. org/10.1016/j.gloplacha.2010.04.008

8. Notebaert B, Verstraeten G (2010) Sensitivity of West and Central European river systems to environmental changes during the Holocene: a review. Earth Sci Rev 103:163-182. https://doi.org/10.1016/j.earsc irev.2010.09.009

9. Broothaerts N, Verstraeten G, Notebaert B et al (2013) Sensitivity of floodplain geoecology to human impact: a Holocene perspective for the headwaters of the Dijle catchment, central Belgium. Holocene 23:1403-1414. https://doi.org/10.1177/0959683613489583

10. Elkins TH (1953) THE brown coal industry of Germany. Geography 38:18-29

11. Heyvaert VMA, Walstra J (2016) The role of long-term human impact on avulsion and fan development. Earth Surf Process Landforms 41:2137-2152. https://doi.org/10.1002/esp.4011

12. Erkens G, Hoffmann T, Gerlach R et al (2011) Complex fluvial response to Late glacial and Holocene allogenic forcing in the Lower Rhine Valley (Germany). Quatern Sci Rev 30:611-627. https://doi.org/10.1016/j.quasc irev.2010.11.019
13. Kaiser K, Keller N, Brande A et al (2018) A large-scale medieval dam-lake cascade in central Europe: water level dynamics of the Havel River, Berlin-Brandenburg region, Germany. Geoarchaeology 33:237-259. https://doi.org/10.1002/gea.21649

14. Dotterweich M (2008) The history of soil erosion and fluvial deposits in small catchments of central Europe: deciphering the long-term interaction between humans and the environment-a review. Geomorphology 101:192-208. https://doi.org/10.1016/j.geomorph.2008.05.023

15. Dreibrodt S, Lubos C, Terhorst B et al (2010) Historical soil erosion by water in Germany: scales and archives, chronology, research perspectives. Quatern Int 222:80-95. https://doi.org/10.1016/j.quain t.2009.06.014

16. Droste PJ (2003) Wasserbau und Wassermühlen an der Mittleren Rur: Die Kernlande des Herzogtums Jülich 8.-18. Jahrhundert. Zugl.: Aachen, Tech. Univ., Diss., 1999. Aachener Studien zur älteren Energiegeschichte, vol 9. Shaker, Aachen

17. Brykała D, Podgórski Z (2020) Evolution of landscapes influenced by watermills, based on examples from Northern Poland. Landsc Urban Plann 198:103798. https://doi.org/10.1016/j.landurbplan.2020.103798

18. Moor JJW de (2007) Human impact on Holocene catchment development and fluvial processes: The Geul River catchment, SE Netherlands. Dissertation, Vrije Universiteit Amsterdam

19. Gibling MR (2018) River systems and the Anthropocene: a late Pleistocene and Holocene timeline for human influence. Quaternary 1:21. https://doi.org/10.3390/quat1030021

20. Brown AG (1997) Alluvial geoarchaeology: Floodplain archaeology and environmental change. Cambridge manuals in archeology. Cambridge University Press, Cambridge

21. Frings RM, Gehres N, Promny M et al (2014) Today's sediment budget of the Rhine River channel, focusing on the Upper Rhine Graben and Rhenish Massif. Geomorphology 204:573-587. https://doi. org/10.1016/j.geomorph.2013.08.035

22. Committee on Rivers and Harbors (1914) Waterway connecting the Tombigbee and Tennessee Rivers. Protocol, Report (United States. Congress House.)

23. Lespez L, Viel V, Rollet AJ et al (2015) The anthropogenic nature of present-day low energy rivers in western France and implications for current restoration projects. Geomorphology 251:64-76. https://doi. org/10.1016/j.geomorph.2015.05.015

24. Curulli Gl (2018) Ghost industries: industrial water landscapes on the Willamette River in Oregon. Altralinea Edizioni, Firenze

25. Barca S (2010) Enclosing water: nature and political economy in a Mediterranean valley 1796-1916, 1 publ. White Horse Press, Winwick Cambridgeshire

26. Borsos B, Sendzimir J (2018) The Tisza River: managing a Lowland River in the Carpathian Basin. In: Schmutz S, Sendzimir J (eds) Riverine ecosystem management, vol 49. Springer International Publishing, Cham pp 541-560

27. Haidvogl G (2018) Historic milestones of human river uses and ecological impacts. In: Schmutz S, Sendzimir J (eds) Riverine ecosystem management, vol 55. Springer International Publishing, Cham, pp 19-39

28. Winiwarter $V$, Haidvogl G, Hohensinner S et al (2016) The long-term evolution of urban waters and their nineteenth century transformation in European cities. A comparative environmental history. Water Hist 8:209-233. https://doi.org/10.1007/s12685-016-0172-z

29. Schmutz S, Sendzimir J (eds) (2018) Riverine ecosystem management. Springer International Publishing, Cham

30. Sendzimir J, Schmutz S (2018) Challenges in riverine ecosystem management. In: Schmutz S, Sendzimir J (eds) Riverine ecosystem management, vol 69. Springer International Publishing, Cham, pp 1-16

31. Ebenstein A (2012) The consequences of industrialization: evidence from water pollution and digestive cancers in China. Rev Econ Stat 94:186-201

32. Páll E, Niculae M, Kiss T et al (2013) Human impact on the microbiological water quality of the rivers. J Med Microbiol 62:1635-1640. https:// doi.org/10.1099/jmm.0.055749-0

33. Cai X, Rosegrant MW, Ringler C (2003) Physical and economic efficiency of water use in the river basin: Implications for efficient water management. Water Resour Res 39:175. https://doi.org/10.1029/2001WR000748

34. Hogeboom RJ, Knook L, Hoekstra AY (2018) The blue water footprint of the world's artificial reservoirs for hydroelectricity, irrigation, residential 
and industrial water supply, flood protection, fishing and recreation. Adv Water Resour 113:285-294. https://doi.org/10.1016/j.advwa tres.2018.01.028

35. Messerli B, Grosjean M, Hofer T et al (2000) From nature-dominated to human-dominated environmental changes. Quatern Sci Rev 19:459-479. https://doi.org/10.1016/S0277-3791(99)00075-X

36. Arheimer B, Donnelly C, Lindström G (2017) Regulation of snow-fed rivers affects flow regimes more than climate change. Nat Commun 8:62. https://doi.org/10.1038/s41467-017-00092-8

37. WFD (2000) "Directive 2000/60/EC of the European parliament and of the council of 23 October 2000 establishing a framework for Community action in the field of water policy" or, in short, the EU Water Framework Directive. Off J Eur Commun L 327:1-72

38. Castree N (2014) The Anthropocene and geography l: the back story. Geography Compass 8:436-449. https://doi.org/10.1111/gec3.12141

39. Gale SJ, Hoare PG (2012) The stratigraphic status of the Anthropocene. Holocene 22:1491-1494. https://doi.org/10.1177/0959683612449764

40. Coenen M, Schüler V (2004) Braunkohle an Rur und Inde. Die Reihe Arbeitswelten, Sutton, Erfurt

41. Esser V, Buchty-Lemke M, Schulte P et al (2020) Signatures of recent pollution profiles in comparable central European rivers-examples from the international River Basin District Meuse. CATENA 193:104646. https ://doi.org/10.1016/j.catena.2020.104646

42. Paul J (1994) Grenzen der Belastbarkeit: Die Flüsse Rur (Roer) und Inde im Industriezeitalter. Forum Jülicher Geschichte, vol 10. Joseph-KuhlGesellschaft zur Geschichte der Stadt Jülich und des Jülicher Landes, Jülich

43. Lehmkuhl F (2011) Die Entstehung des heutigen Naturraums und seine Nutzung. In: Kraus T, Pohle F (eds) Die natürlichen Grundlagen—von der Vorgeschichte bis zu den Karolingern, pp 87-129

44. Nilson E, Lehmkuhl $F$ (2006) Landschaftstransformation am Eifelnordrand seit Beginn der industriellen Revolution: Räumliche Auswirkungen geogener Faktoren. Natur am Niederrhein (2):47-60

45. Tu M, Hall MJ, de Laat PJM et al. (2004) Extreme floods in the Meuse basin over the past century: aggravated by land-use change? In: Douben N, van Os AG (eds) NCR-days 2003: Dealing with Floods within Constraints. November 6-8

46. Umwelt B, Naturschutz und Reaktorsicherheit (1986) Wasserhaushaltsgesetz: WHG. Bundesgesetzblatt 1986(50):1529-1543

47. MKULNV NRW (2015) MAAS SÜD NRW: Steckbriefe der Planungseinheiten in den nordrhein-westfälischen Anteilen von Rhein, Weser, Ems und Maas, Bewirtschaftungsplan 2016-2021. Oberflächengewässer und Grundwasser Teileinzugsgebiet Maas/Maas Süd NRW

48. Downs PW, Gregory KJ (2004) River channel management: towards sustainable catchment hydrosystems. Distributed in the USA by Oxford University Press, London, New York

49. Andersen O, Crow TR, Lietz SM et al (1996) Transformation of a landscape in the upper mid-west, USA: the history of the lower St. Croix River valley, 1830 to present. Landsc Urban Plann 35:247-267. https:// doi.org/10.1016/S0169-2046(96)00304-0

50. Furusho C, Vidaurre R, La Jeunesse I et al (2016) Cross-cutting perspective freshwater. In: Bressers H, Bressers N, Larrue C (eds) Governance for drought resilience, vol 29. Springer International Publishing, Cham, pp 217-230

51. Tockner K, Stanford JA (2002) Riverine flood plains: present state and future trends. Envir Conserv 29:308-330. https://doi.org/10.1017/S0376 $89290200022 X$

52. Koenzen U (2005) Fluss- und Stromauen in Deutschland - Typologie und Leitbilder -: Ergebnisse des F+E-Vorhabens "Typologie und Leitbildentwicklung für Flussauen in der Bundesrepublik Deutschland" des Bundesamtes für Naturschutz; FKZ: 80382 100. Zugl.: Köln, Univ., Diss., 2005. Angewandte Landschaftsökologie, vol 65. Bundesamt für Naturschutz, Bonn-Bad Godesberg

53. Notebaert B, Broothaerts N, Verstraeten G (2018) Evidence of anthropogenic tipping points in fluvial dynamics in Europe. Global Planet Change 164:27-38. https://doi.org/10.1016/j.gloplacha.2018.02.008

54. Khan S, Fryirs K (2020) An approach for assessing geomorphic river sensitivity across a catchment based on analysis of historical capacity for adjustment. Geomorphology 359:107135. https://doi.org/10.1016/j. geomorph.2020.107135
55. Brierley GJ, Fryirs KA (2005) Geomorphology and river management: applications of the river styles framework. Blackwell Publishing, Malden, Oxford, Victoria

56. Erskine W, Melville M, Page KJ et al (1982) Cutoff and Oxbow lake. Aust Geogr 15:174-180. https://doi.org/10.1080/00049188208702813

57. Pottgiesser T, Sommerhäuser M (2008) BEGLEITTEXT: Aktualisierung der Steckbriefe der bundesdeutschen Fließgewässertypen-Steckbriefe (Teil A) und Ergänzung der Steckbriefe der deutschen Fließgewässertypen um typspezifische Referenzbedingungen und Bewertungsverfahren aller Qualitätselemente (Teil B). Umweltbundesamt, LAWA. https ://www.gewaesser-bewertung.de/files/steckbriefe_fliessgewaesser typen_april2008.pdf

58. Kondolf GM, Piégay H (eds) (2016) Tools in fluvial geomorphology. Advancing river restoration and management, 2 nd edn. Wiley Blackwell, Chichester, West Sussex, Hoboken, NJ

59. Miall AD (1977) A review of the braided-river depositional environment. Earth Sci Rev 13:1-62. https://doi.org/10.1016/0012-8252(77)90055-1

60. de Moor JJW, Kasse C, van Balen R et al (2008) Human and climate impact on catchment development during the Holocene-Geul River, the Netherlands. Geomorphology 98:316-339. https://doi. org/10.1016/j.geomorph.2006.12.033

61. Kleinhans MG, de Vries B, Braat L et al (2018) Living landscapes: Muddy and vegetated floodplain effects on fluvial pattern in an incised river. Earth Surf Process Landforms 43:2948-2963. https://doi.org/10.1002/ esp. 4437

62. Scorpio V, Zen S, Bertoldi W et al (2018) Channelization of a large Alpine river: what is left of its original morphodynamics? Earth Surf Process Landforms 43:1044-1062. https://doi.org/10.1002/esp.4303

63. Knighton DA, Nanson GC (1993) Anastomosis and the continuum of channel pattern. Earth Surf Process Landforms 18:613-625. https://doi. org/10.1002/esp.3290180705

64. Vandenberghe J, de Moor JJW, Spanjaard G (2012) Natural change and human impact in a present-day fluvial catchment: the Geul River, Southern Netherlands. Geomorphology 159-160:1-14. https://doi. org/10.1016/j.geomorph.2011.12.034

65. Mikuś P, Wyżga B, Walusiak E et al (2019) Island development in a mountain river subjected to passive restoration: the Raba River, Polish Carpathians. Sci Total Environ 660:406-420. https://doi.org/10.1016/j. scitotenv.2018.12.475

66. Hudson PF, van der Hout E, Verdaasdonk M (2019) (Re)Development of fluvial islands along the lower Mississippi River over five decades, 1965-2015. Geomorphology 331:78-91. https://doi.org/10.1016/j. geomorph.2018.11.005

67. Bravard J-P, Gaydou P (2015) Historical development and integrated management of the Rhône River Floodplain, from the Alps to the Camargue Delta, France. In: Hudson PF, Middelkoop H (eds) Geomorphic approaches to integrated floodplain management of lowland fluvial systems in North America and Europe, vol 29. Springer. New York, New York, NY, pp 289-320

68. Rinaldi M, Mengoni B, Luppi L et al (2008) Numerical simulation of hydrodynamics and bank erosion in a river bend. Water Resour Res 44:1356. https://doi.org/10.1029/2008WR007008

69. Rommens T, Verstraeten G, Bogman P et al (2006) Holocene alluvial sediment storage in a small river catchment in the loess area of central Belgium. Geomorphology 77:187-201. https://doi.org/10.1016/j.geomo rph.2006.01.028

70. Nilson E (2006) Flusslandschaften im Wandel: Untersuchungen zur Mäanderentwicklung an zwei Maas-Tributären anhand von historischem Bild- und Kartenmaterial. In: Reineke T, Lehmkuhl F, Blümel H (eds) Grenzüberschreitendes integratives Gewässermanagement, 1. Aufl. Academia-Verl., Sankt Augustin

71. Kufeld M, Lange J, Hausmann B (2010) Das Einzugsgebiet der Rur : Ergebnisbericht der im Rahmen des AMICE-Projekts durchgeführten Literaturrecherche; AMICE, meus, maas; INTERREG IVB North West Europe Project (number 074C). EPAMA, Charleville-Mézières

72. Bogena H (2005) MOSYRUR: Water balance analysis in the Rur basin, 1. Aufl. Schriften des Forschungszentrums Jülich Reihe Umwelt, vol 52. Forschungszentrum Zentralbibliothek, Jülich

73. MKULNV NRW (2014) Maas Süd: Steckbriefe der Planungseinheiten in den nordrhein-westfälischen Anteilen von Rhein, Weser, Ems und Maas. 
Oberflächengewässer und Grundwasser Teileinzugsgebiet Maas/Maas Süd NRW (Stand: Juli 2014), Düsseldorf

74. Dussart F, Claude J (1971) Études récentes sur l'Eifel. In: MérenneSchoumaker B (ed) Bulletin de la Société géographique de Liège. Liege, Belgium, pp 163-176

75. Özerol G, Troeltzsch J (2016) Cross-cutting perspective on agriculture. In: Bressers H, Bressers N, Larrue C (eds) Governance for drought resilience, vol 11. Springer International Publishing, Cham, pp 203-215

76. Bressers H, Bressers N, Larrue C (eds) (2016) Governance for drought resilience. Springer International Publishing, Cham

77. Nilson E (2006) Räumlich-strukturelle und zeitlich-dynamische Aspekte des Landnutzungswandels im Dreiländereck Belgien-NiederlandeDeutschland: Eine Analyse mittels eines multitemporalen, multifaktoriellen und grenzübergreifenden Geographischen Informationssystems. Aachen, Techn. Hochsch., Diss., 2006. http://darwin.bth.rwth-aache n.de/opus3/volltexte/2006/1612/pdf/Nilson_Enno.pdf

78. Wagner A, Koenzen U, Lohr $\mathrm{H}$ et al (2013) Die „beschleunigte“ Befüllung des Tagebaurestsees Inden aus der Rur. Wasserwirtsch 103:66-71. https ://doi.org/10.1365/s35147-013-0426-y

79. UBA (2014) Hydromorphologische Steckbriefe der deutschen Fließgewässertypen: Anhang 1 von "Strategien zur Optimierung von Fließgewässer-Renaturierungsmaßnahmen und ihrer Erfolgskontrolle", Dessau-Roßlau

80. MNULV (2005) Gewässerstrukturgüte in Nordrhein-Westfalen: Bericht 2005. Landesumweltamt Nordrhein-Westfalen, Essen. https://www. lanuv.nrw.de/fileadmin/lanuvpubl/lua/gwstrukturbericht2005.pdf. Accessed 15 June 2020

81. Schumm SA (1985) Patterns of alluvial rivers. Annu Rev Earth Planet Sci 13:5-27. https://doi.org/10.1146/annurev.ea.13.050185.000253

82. Rinaldi M, Gurnell AM, del Tánago MG et al (2016) Classification of river morphology and hydrology to support management and restoration. Aquat Sci 78:17-33. https://doi.org/10.1007/s00027-015-0438-z

83. Nanson GC, Knighton AD (1996) Anabranching rivers their cause character and classification. Earth Surf Process Landforms 21:217-239. https://doi.org/10.1002/(SICI)1096-9837(199603)21:3\%3c217:AID-ESP61 $1 \% 3$ e3.0. $\mathrm{CO} \cdot 2-\mathrm{U}$

84. Deutsche Vereinigung für Wasserwirtschaft, Abwasser und Abfall (2018) Begriffe aus der Gewässerunterhaltung und Gewässerentwicklung, Juni 2018. DWA-Regelwerk, M 600. Deutsche Vereinigung für Wasserwirtschaft Abwasser und Abfall, Hennef

85. Roccati A, Faccini F, Luino F et al (2019) Morphological changes and human impact in the Entella River floodplain (Northern Italy) from the 17th century. CATENA 182:104122. https://doi.org/10.1016/j.caten a.2019.104122

86. Guth PL (2011) Drainage basin morphometry: a global snapshot from the shuttle radar topography mission. Hydrol Earth Syst Sci 15:20912099. https://doi.org/10.5194/hess-15-2091-2011

87. Brookes A (1987) The distribution and management of channelized streams in Denmark. Regul Rivers: Res Mgmt 1:3-16. https://doi. org/10.1002/rrr.3450010103

88. Brierley GJ, Fryirs KA (2008) Geomorphology and river management: applications of the river styles framework. Blackwell, Malden, Mass

89. Bromley C (2008) The morphodynamics of sediment movement through a reservoir during dam removal. PhD thesis, University of Nottingham

90. East AE, Pess GR, Bountry JA et al (2015) Large-scale dam removal on the Elwha River, Washington, USA: River channel and floodplain geomorphic change. Geomorphology 228:765-786. https://doi. org/10.1016/j.geomorph.2014.08.028

91. Wickert AD, Schildgen TF (2019) Long-profile evolution of transportlimited gravel-bed rivers. Earth Surf Dynam 7:17-43. https://doi. org/10.5194/esurf-7-17-2019

92. Brice JC (1984) Planform Properties of Meandering Rivers. In: Elliott CM (ed) River meandering: Proceedings of the Conference Rivers ' 83. American Society of Civil Engineers, $N$

93. Chin A (2006) Urban transformation of river landscapes in a global context. Geomorphology 79:460-487. https://doi.org/10.1016/j.geomo rph.2006.06.033

94. Odgaard AJ (2017) River management with submerged vanes. In: Sharma N (ed) River system analysis and management. Springer Singapore, Singapore
95. Tiwari H, Khan A, Sharma N (2017) Emerging methodologies for turbulence characterization in river dynamics study. In: Sharma N (ed) River system analysis and management, vol 28. Springer Singapore, Singapore, pp 167-186

96. Mahanta C, Saikia L (2017) Sediment dynamics in a large alluvial river: characterization of materials and processes and management challenges. In: Sharma N (ed) River system analysis and management, vol 114. Springer Singapore, Singapore, pp 47-71

97. Haidvogl G, Hohensinner S, Preis S (2011) Rekonstruktion historischer flusslandschaften als grundlage im gewässermanagement-potential und limits. Österr Wasser-und Abfallw 63:174-182. https://doi. org/10.1007/s00506-011-0335-1

98. Downs PW, Thorne CR (2000) Rehabilitation of a lowland river: Reconciling flood defence with habitat diversity and geomorphological sustainability. J Environ Manage 58:249-268. https://doi.org/10.1006/ jema.2000.0327

99. Wasserverband Eifel-Rur (ed) (1999) 100 Jahre Wasserwirtschaft in der Nordeifel, Düren. ISBN 3927312452

100. Wermelskirchen E (1963) Die Regulierung der Rur zwischen Düren und der Landesgrenze unter besonderer Berücksichtigung der Kreis-Jülicher Verhältnisse. In: Jülich K (ed) Heimatkalender des Kreises Jülich, pp 83-90

101. Castro JM, Thorne CR (2019) The stream evolution triangle: Integrating geology, hydrology, and biology. River Res Applic 35:315-326. https:// doi.org/10.1002/rra.3421

102. Mazumder SK (2017) Behaviour and training of river near bridges and barrages: some case studies. In: Sharma N (ed) River system analysis and management, vol 106. Springer Singapore, Singapore, pp 263-277

103. Mulu A, Dwarakish GS (2015) Different approach for using trap efficiency for estimation of reservoir sedimentation. An overview aquatic. Procedia 4:847-852. https://doi.org/10.1016/j.aqpro.2015.02.106

104. Ruddiman WF (2013) The Anthropocene. Annu Rev Earth Planet Sci 41:45-68. https://doi.org/10.1146/annurev-earth-050212-123944

105. Amoros C (2001) The concept of habitat diversity between and within ecosystems applied to river side-arm restoration. Environ Manage 28:805-817. https://doi.org/10.1007/s002670010263

106. Škarpich V, Horáček M, Galia T et al (2016) The effects of river patterns on riparian vegetation: a comparison of anabranching and singlethread incised channels. Moravian Geogr Rep 24:24-31. https://doi. org/10.1515/mgr-2016-0014

107. Halley DJ, Saveljev AP, Rosell F (2020) Population and distribution of beavers Castor fiber and Castor canadensis in Eurasia. Mam Rev 10:23. https://doi.org/10.1111/mam.12216

108. Dalbeck L (2012) Die Rückkehr der Biber - eine Erfolgsgeschichte des Artenschutzes. Zeitschrift des Kölner Zoos (4):167-180. http://www. koelnerzoo.de/images/pdf/Zeitschriften/Zeitschrift_2012_04.pdf. Accessed 3 Feb 2021

109. Robinson CT, Schweizer P, Larsen A et al (2020) Beaver effects on macroinvertebrate assemblages in two streams with contrasting morphology. Sci Total Environ 722:137899. https://doi.org/10.1016/j.scito tenv.2020.137899

110. Merckx T (2015) Rewilding: pitfalls and opportunities for moths and butterflies. In: Pereira HM, Navarro LM (eds) Rewilding European landscapes, vol 14. Springer International Publishing, Cham, pp 107-125

111. Buchty-Lemke M, Lehmkuhl F (2018) Impact of abandoned water mills on Central European foothills to lowland rivers: a reach scale example from the Wurm River, Germany. Geogr Ann Ser A Phys Geogr 100:221-239. https://doi.org/10.1080/04353676.2018.1425621

112. Maaß A-L, Schüttrumpf H (2019) Elevated floodplains and net channel incision as a result of the construction and removal of water mills. Geogr Ann Ser A, Phys Geogr 101:157-176. https://doi. org/10.1080/04353676.2019.1574209

113. Trebilcock C (2014) Industrialisation of the continental powers 1780-1914. The Taylor and Francis, Hoboken

114. Kukliński AP (1989) Industrialization in Poland_experiences and prospects. GeoJ Spat Integr Soc Sci Hum 18:141-150. https://doi. org/10.1007/BF01207088

115. Gołębiowski C (2016) Inland Water Transport in Poland. Transp Res Proc 14:223-232. https://doi.org/10.1016/j.trpro.2016.05.058 
116. Witkowski K (2020) Man's impact on the transformation of channel patterns (the Skawa River, southern Poland). River Res Applic 1126:659. https://doi.org/10.1002/rra.3702

117. Michalczyk Z (1997) Anthropogenic changes in water conditions in the Lublin Area. In: Maruszczak H (ed) Anthropogenic impact on water conditions: (Vistula and Oder river basins). Polish Acad. of Sciences Inst. of Geography and Spatial Organization, Warszawa

118. Igliński B (2019) Hydro energy in Poland: the history, current state, potential, SWOT analysis, environmental aspects. Int J Energ Water Res 3:61-72. https://doi.org/10.1007/s42108-019-00008-w

119. Glińska-Lewczuk K, Burandt P (2011) Effect of river straightening on the hydrochemical properties of floodplain lakes: observations from the Łyna and Drwęca Rivers, N Poland. Ecol Eng 37:786-795. https://doi. org/10.1016/j.ecoleng.2010.07.028

120. Downs PW, Piégay H (2019) Catchment-scale cumulative impact of human activities on river channels in the late Anthropocene: implications, limitations, prospect. Geomorphology 338:88-104. https://doi. org/10.1016/j.geomorph.2019.03.021

121. KirkT (1999) Small-scale hydro-power in the UK. Water Environ J 13:207-212. https://doi.org/10.1111/j.1747-6593.1999.tb01036.x

122. Wrigley EA (1990) Continuity, chance and change the character of the industrial revolution in England. Ellen McArthur lectures, vol 1987. Cambridge University Press, New York

123. Johnson PA, Floud R (eds) (2004) The Cambridge economic history of modern Britain, vol 1 Industrialisation 1700-1860. Cambridge: Cambridge University Press

124. Willan TS (1964) River navigation in England 1600-1750. F. Cass, London

125. Smith LM, Winkley BR (1996) The response of the Lower Mississippi River to river engineering. Eng Geol 45:433-455. https://doi. org/10.1016/S0013-7952(96)00025-7

126. Turnbull G (1987) Canals, coal and regional growth during the industrial revolution. Econ History Rev 40:537. https://doi.org/10.2307/2596392

127. Habersack H, Piégay H (2007) 27 River restoration in the Alps and their surroundings: past experience and future challenges. In: Gravel-Bed Rivers VI: from process understanding to river restoration, vol 11, $\mathrm{p}$ 703-735. Elsevier

128. Jakobsson E (2002) Industrialization of rivers: a water system approach to hydropower development. Know Techn Pol 14:41-56. https://doi. org/10.1007/s12130-002-1014-0

129. Paul J (1999) Vom reißenden Gewässer zum gebändigten Fluß.: Die Geschichte der Wasserwirtschaft im Flußgebiet der Rur vom 16. Jahrundert bis in die Zeit um 1960. In: Wasserverband Eifel-Rur (ed) 100 Jahre Wasserwirtschaft in der Nordeifel, Düren, pp 51-62
130. Schwind W (1984) Der Eifelwald im Wandel der Jahrhunderte ausgehend von Untersuchungen in der Vulkaneifel. Eifelverein, Düren

131. Intze O (1906) Die geschichtliche Entwicklung, die Zwecke und der Bau der Talsperren. Springer, Berlin, Heidelberg

132. Franzius O, Proetel H (1927) Der wasserwirtschaftliche Ausbau der Rur (Roer) in der Nord-Eifel: Denkschrift und vergleichende Entwürfe. Hamel'sche Druckerei, Düren

133. Goedeking A (2012) Wann und wie treten Erfolge ein? Veränderungen von Renaturierungen und Erfolgskontrollen an der Eifel-Rur. Natur in NRW (1):43-45

134. Völker J, Mohaupt V (2016) Die Wasserrahmenrichtlinie: Deutschlands Gewässer 2015. UMWELTBUNDESAMT, Bonn. https://www.umweltbund esamt.de/sites/default/files/medien/1968/publikationen/final_brosc hure_wasserrahm_enrichtlinie_bf_112116.pdf. Accessed 13 Oct 2020

135. Zorn W, Warm R (1967) ZUR BETRIEBSSTRUKTUR DER RHEINISCHEN INDUSTRIE UM 1820: Fritz Redlich Zum 75. Geburtstag. Tradition: Zeitschrift für Firmengeschichte und Unternehmerbiographie 12: $497-510$

136. European Environment Agency (2016) European Digital Elevation Model (EU-DEM). https://land.copernicus.eu/imagery-in-situ/eu-dem. Accessed 19 Oct 2020

137. Geofabrik GmbH (2018) gis_osm_waterways_free_1. CC BY-SA 2.0. download.geofabrik.de. Accessed 19 Oct 2020

138. Landesbetrieb Information und Technik Nordrhein-Westfalen (2020) gsk3c_EPSG25832_Shape.zip. dl-de-by-2.0. https://www.opengeodat a.nrw.de/produkte/umwelt_klima/wasser/gsk3c/. Accessed 20 Oct 2020

139. Geobasis NRW 2018 Basis DLM (2018): Digitales Landschaftsmodel (DLM). dl-de/by-2-0. http://www.bezreg-koeln.de/brk internet/geoba sis/landschaftsmodelle/basis_dlm/index.html,. Accessed 20 Oct 2020

140. Eurostat (2020) Countries 2016: ref-countries-2016-01m.shp. https:// ec.europa.eu/eurostat/de/web/gisco/geodata/reference-data/admin istrative-units-statistical-units/countries. Accessed 20 Oct 2020

141. European Environment Agency (2016) CLC 2018. https://land.coper nicus.eu/pan-european/corine-land-cover/clc2018. Accessed 19 Oct 2020

\section{Publisher's Note}

Springer Nature remains neutral with regard to jurisdictional claims in published maps and institutional affiliations.

\section{Submit your manuscript to a SpringerOpen ${ }^{\circ}$ journal and benefit from:}

- Convenient online submission

- Rigorous peer review

- Open access: articles freely available online

- High visibility within the field

- Retaining the copyright to your article

Submit your next manuscript at $\boldsymbol{\nabla}$ springeropen.com 